\title{
Son 15 Yılda Yayımlanan İlk ve Ortaöğretim İngilizce Dersi Öğretim Programları Üzerine Bir Analiz ${ }^{1}$
}

Esin Yücel $^{2}$, Kadriye Dimici ${ }^{3}$, Burçin Yıldız ${ }^{4}$ ve Nilay T. Bümen ${ }^{5}$

\section{$\ddot{\mathbf{O} z}$}

Son 15 yıla ait İngilizce dersi öğretim programlarının çeşitli ölçütler çerçevesinde incelendiği bu çalışmada, programlardaki gelişmelerin anlaşılması hedeflenmiştir. Çalışmada doküman analizi yöntemi kullanılmış, ulaşılabilen iki ilköğretim (2006 ve 2013) ve dört ortaöğretim (2002, 2011, 2014 ve 2016) İngilizce dersi öğretim programı, alanyazındaki program tasarım ilkeleri (kapsam, aşamalılık, süreklilik, kaynaşıklık, denge, kullanışlılık ve esneklik) çerçevesinde analiz edilmiştir. Bulgulara göre, ilköğretim ve ortaöğretim İngilizce dersi öğretim programlarında, dil eğitimi alanında dünyadaki gelişmelerin takip edildiği ve yeniliklerin programlara dâhil edilmeye çalışıldığı görülmüştür. İlköğretim programlarının, esneklik ilkesi dışında genel olarak tasarım ilkelerine uygun olduğu ancak önerilen sürelerin yetersiz kaldığı sonucuna varılmıştır. Ortaöğretim programlarının analizinden elde edilen bulgular ise, programlarda iletişimsel yaklaşımın benimsendiğini ancak araştırmalara göre bu yaklaşımın öğretmenler tarafından tam olarak anlaşılmadığını, dolayısıyla da uygulanamadığını göstermiştir. Bununla birlikte, tasarım ilkelerinden aşamalılık ve sürekliliğe özen gösterildiği ancak kapsam, denge, kullanışl1lık ve esnekliğin göz ardı edildiği belirlenmiştir. Özellikle 2011 ortaöğretim programında hedefler ve içeriğin belirlenmesinde öğrencilerin ilgileri, ihtiyaçları ve hazırbulunuşluk düzeylerinin dikkate alınmaması, programın çok uzun ve karmaşık olması, önerilen sürenin yetersiz olması; denge, kullanışlılık ve esneklik ilkelerinin ihmal edildiğini düşündürmektedir. Bulgular 1şığında kuram ve uygulamaya dönük öneriler sunulmuştur.

Anahtar sözcükler: Öğretim programları, ilköğretim İngilizce dersi öğretim programları, ortaöğretim İngilizce dersi öğretim programları, İngilizce öğretimi

\footnotetext{
${ }^{1}$ Bu çalışma 11-14 Mayıs 2017 tarihlerinde gerçekleştirilen IV. Uluslararası Avrasya Eğitim Araştırmaları Kongresi'nde sözlü bildiri olarak sunulmuştur.

2Okutman, Ege Üniversitesi Yabancı Diller Yüksekokulu, Bornova / İzmir

3,4Okutman, İzmir Kâtip Çelebi Üniversitesi Yabancı Diller Yüksekokulu, Çiğli / İzmir

5Prof. Dr., Ege Üniversitesi Eğitim Bilimleri Bölümü Eğitim Programları ve Öğretim Anabilim Dalı, Bornova / İzmir
} 
An Analysis of the Primary and Secondary School English Language Curricula

Published Over the Last 15 Years

\begin{abstract}
This study aims at understanding the progress of English language curricula published over the last 15 years. A qualitative research method, document analysis was preferred; two primary school (2006 \& 2013) and four secondary school (2002, 2011, 2014 \& 2016) English language curricula were analyzed within the scope of the principles of curriculum design (scope, sequence, continuity, articulation, balance, user-friendliness and flexibility). The findings indicated that curriculum design principles and the innovations in the field of language education were considered in the curricula. The primary school curricula were compatible with the principles of curriculum design except for flexibility as they failed to satisfy the time proposed. Communicative approach was adopted in secondary school curricula but could not be practiced as suggested by other studies. They were attentive to sequence and continuity whereas scope, balance, user-friendliness and flexibility were ignored at times. Especially, in the 2011 secondary school program the interests and needs of the students were ignored in content and objective design. It was too long, complicated and the time suggested was not enough for the implementation, all causing the neglect of balance, user-friendliness and flexibility. In the light of these findings, suggestions for theory and practice are offered.
\end{abstract}

Keywords: Curriculum, primary school English language curricula, secondary school English language curricula, English language education 


\section{Giriş}

Bilgi ve iletişim teknolojilerindeki gelişmelere paralel olarak İngilizce, 21. yüzyıl dünyasının ortak dili haline gelmiştir. İngilizcenin yabancı dil aracı olarak kültürel, politik ve ekonomik ilişkilerde bireylere ve ülkelere yarar sağlaması, okullarda yaygın olarak öğretilmesine neden olmaktadır. Çağın teknolojisini ve bilimini öğrenmek ve üretmek zorunda olan Türkiye'de de yabancı dil öğrenmenin gerekliliği vurgusu çeşitli eğitim tartışmalarında ve program geliştirme çalışmalarında gündeme gelmiş; 1950’lerden sonra ise İngilizce, okullarda zorunlu ya da seçmeli olarak \%98,4 oranıyla en çok öğretilen yabancı dil olmuştur (Genç, 1999, akt. Seçkin, 2011).

Cumhuriyetin ilanından sonra başlayan eğitim reformlarında modern toplum yaratmak amacıyla yabancı dil öğrenmenin gerekliliği vurgulanmış ancak yabancı dil için öğretim programları 1980'lerde sistematik olarak hazırlanmaya başlanabilmiştir. Türkiye'de yasalar, milli eğitim politikasının geliştirilmesini, bu politikayı uygulamaya dönüştürecek programların hazırlanmasını ve uygulamanın denetlenmesini Milli Eğitim Bakanlığı (MEB) Talim Terbiye Kurulu Başkanlığı'na yüklediğinden (Varış, 1989), yabancı dil öğretimi programları merkezi olarak MEB tarafından hazırlanmakta ve ülke genelinde uygulanmaktadır. Yabancı dil öğretimiyle ilgili olarak yapılan son değişikliklere göre 2013 yılında Talim Terbiye Kurulu Başkanlığı'nın (TTKB) kararıyla İngilizce dersleri 2. ve 3. sınıftan itibaren programda yer almaya başlamıştır (TTKB, 2013). Anadolu ve Süper liselerde ise İngilizce hazırlık programları 2005 yılında standardizasyon sağlamak amacıyla kaldırılmış ve İngilizce dersleri 9. sinıfta haftada 10 saat ve 10., 11. ve 12. sinıflarda ise haftada dört saat olmak üzere yeniden tasarlanmıştır (Kırkgöz, 2007). Ancak İngilizce eğitiminde ilköğretimden yükseköğretime kadar her kademede yıllardır yapılan pek çok iyileştirme çabasına rağmen, hâlâ istenilen düzeyde başarı sağlanamamış ve bu durum 2014 yılında Türkiye Ekonomi Politikaları Araştırma Vakfı (TEPAV) tarafından yapılan araştırma raporlarına da Türkiye'nin İngilizce öğretimi alanında beklenenden düşük performans gösterdiği şeklinde yansımıştır (TEPAV, 2014).

Eğitimde sistem yaklaşımına göre eğitim programları, verimliliği etkileyen faktörler ve planlı eğitimde mutlak suretle olması gereken girdiler arasındadır (Tan ve Erdoğan, 2004). Bu bağlamda Posner'a (1995) göre, uygulamaya konulan bir programın etkililiği konusunda yargıya varabilmek için programın öğelerindeki eksikliklerin ve aksaklıkların bir ölçüte dayandırılarak belirlenmesi gerekmektedir. Ancak ilgili alanyazın incelendiğinde, İngilizce 
öğretim programlarına yönelik analizlerin çoğunlukla öğrenci ve öğretmen görüşlerine dayalı olarak yapılan değerlendirme çalışmaları olduğu görülmekte (Alkan ve Arslan, 2014; Çelik ve Kasapoğlu, 2014; Demirtaş ve Erdem, 2015; Dönmez, 2010; Hismanoğlu, 2013; İnceçay, 2012; Kırkgöz, 2008; Kızıldağ, 2009; Merter, Kartal ve Çağlar, 2012; Seçkin, 2011; Topkaya ve Küçük, 2010; Yıldıran ve Tanrıseven, 2015), son yıllarda uygulanan öğretim programlarının karşılaştırmalı olarak incelendiği bir araştırmaya rastlanmamaktadır. $\mathrm{Bu}$ bağlamda yapılan program değişikliklerinin gerekçelerine ve programların ne yönde ilerlediğine ilişkin yorum yapılması zorlaşmaktadır. Bu eksikliğin giderilmesi ve hazırlanan programların gelişimi konusunda bir yargıya varılabilmesi açısından, bu araştırmada son 15 yılda ilköğretim 2. sınıftan 12. sınıfa kadar uygulanan İngilizce dersi öğretim programları incelenmiştir. $\mathrm{Bu}$ amaç doğrultusunda çalışmada, “2002-2017 yılları arasında yayımlanan İngilizce dersi öğretim programlarının tasarım ilkelerine (kapsam, aşamalılık, süreklilik, kaynaşıklık, denge, kullanışlılık ve esneklik) uygunluğu nasıldır?” sorusuna yanıt aranmıştır. Çalışmada öncelikle son 20 yılda İngilizce dersi öğretim programlarındaki gelişmeler incelenmek istenmiş ancak bazı programların basılı ya da elektronik formlarına ulaşılamadığından son 15 yılda yayımlanan programlar ele alınmıştır.

Araştırmanın, Türkiye'de yabancı dil olarak İngilizce eğitimindeki gelişmelerin izlenebildiği bir kaynak sunması, öğretim programlarının geliştirilmeye açık yönleriyle ilgili çözümler önererek gelecekteki program geliştirme çalışmalarına 1şık tutması açısından katkı sağlayacağı düşünülmektedir. Önceki çalışmalarda tek tek ilgili öğretim programlarına dair incelemeler yapılmış olsa da (Alkan ve Arslan, 2014; Çelik ve Kasapoğlu, 2014; Demirtaş ve Erdem, 2015; Dönmez, 2010; Hismanoğlu, 2013; İnceçay, 2012; Kırkgöz, 2008; Kızıldağ, 2009; Merter, Kartal ve Çağlar, 2012; Seçkin, 2011; Topkaya ve Küçük, 2010; Yıldıran, 2015), son yıllarda yayımlanan İngilizce dersi öğretim programlarını birlikte inceleyen bir çalışmaya rastlanmadığından, bu araştırma önemli bir kaynak niteliği taşıyabilir. Ayrıca 20172018 eğitim öğretim yılında uygulanmak üzere program güncelleme sürecinde olan MEB, bu araştırma sonuçlarından yararlanarak bazı değişiklikleri gerçekleştirebilir.

\section{Yöntem}

$\mathrm{Bu}$ araştırma doküman incelemesi yöntemiyle yapılmıştır. Doküman incelemesi, araştırılması hedeflenen olgu veya olgular hakkında bilgi içeren yazılı materyallerin analizini kapsar. Nitel araştırmada, doküman incelemesi tek başına bir veri toplama yöntemi olabileceği gibi diğer veri toplama yöntemleri ile birlikte de kullanılabilir (Yıldırım ve 
Şimşek, 2013). Doküman incelemesi yaparken izlenecek bir dizi aşama vardır. Bu aşamalar, (1) dokümanlara ulaşma, (2) orijinalliğini kontrol etme, (3) dokümanları anlama, (4) veriyi analiz etme ve (5) veriyi kullanmadır (Yıldırım ve Şimşek, 2013). Araştırmada bu aşamalara uyulması konusunda özen gösterilmiş ve aşağıdaki işlem basamakları takip edilmiştir:

1. İlgili öğretim programlarına ulaşılması ve orijinalliğinin kontrol edilmesi,

2. Alanyazın ışı̆̆ında programların analizinde kullanılacak olan tasarım ilkelerinin belirlenmesi,

3. Programların analizinin belirlenen tasarım ilkelerine göre yapılması, birbirleriyle kıyaslanması ve anlaşılması,

4. Elde edilen verilerin betimlenmesi ve bulgulara ulaşılması,

5. Bulguların ilgili araştırmalarla ilişkilendirilerek yorumlanması ve önerilerin yazilmasi.

\section{Verilerin Elde Edilmesi ve Analizi}

Araştırmanın başlangıcında, son 20 yıla ait ilk ve ortaöğretim İngilizce dersi öğretim programlarına MEB'in resmi internet sayfasından ve internet üzerindeki arama motorları aracılığıyla ulaşılmaya çalışılmıştır. İlgili internet sitelerinde önce 2013 ve 2016 eğitim ve öğretim yıllarına ait İngilizce ilköğretim programlarına, daha sonra ise 2011, 2014 ve 2016 yıllarına ait ortaöğretim programlarına ulaşılmıştır. Önceki yıllara ait programlar için 4982 sayılı Bilgi Edinme Kanunu kapsamında TTKB'ye başvuru yapılmış, ancak programların elektronik posta yoluyla gönderilemeyeceği, arşiv araştırmasına yönelik ilgilinin bizzat yazılı başvuru yapması gerektiği şeklinde bir cevap alınmıştır. Araştırmacıların Ankara'da yaşamamaları ve zaman sınırlılığı nedeniyle arşive bizzat başvuruda bulunulamamıştır. Bu nedenle araştırma, TTKB resmi internet sayfasından indirilen 2006, 2013 yılları İlköğretim İngilizce Dersi Öğretim Programları; 2011, 2014 ve 2016 y1lları Ortaöğretim İngilizce Dersi Öğretim Programları ile "Nadir Kitap" adlı internet sitesinden elde edilen 2002 y1lı Anadolu Lisesi İngilizce Dersi Öğretim Programının incelenmesi yoluyla gerçekleştirilmiştir.

Posner'a (1995, s. 21-23) göre program analizi, belge yüzeyinin altını sondalamayı, satır aralarını okumayı ve dağınık halde bulunan kanıtlara dayalı olarak çıkarımda bulunmayı gerektirmektedir. Bu görüşten hareketle, programların dikkatli bir şekilde analiz edilebilmesi için öncellikle alanyazın taraması yapılmış ve kullanılacak program tasarım ilkeleri belirlenmiştir. Programların betimsel analizine çerçeve oluşturan tasarım ilkeleri, program 
tasarımı ve analizi ile ilgili alanyazın (Doğanay, 2008; Eğitim Reformu Girişimi-ERG, 2005; Gözütok ve diğ., 2013; Hewitt, 2006; Posner, 1995; Sönmez, 2007) dikkate alınarak, Dikbayır'ın (2016) geliştirdiği ve henüz yayınlanmamış bir öğretim programı uyum (curriculum alignment) ölçeği incelenerek, ardından araştırmacıların yaptıkları beyin fırtınası sonucunda oluşturulmuştur. Buna göre programlar kapsam (scope), aşamalılık (sequence), süreklilik (continuity), kaynaşıklık (articulation), denge (balance), kullanışlılık (userfriendliness) ve esneklik (flexibility) ilkelerine dayalı olarak incelenmiştir. $\mathrm{Bu}$ ilkelerin (temaların) açıklamaları ve araştırma kapsamındaki anlamı aşağıda belirtilmiştir:

Hewitt uyumu (2006); programın kapsam, aşamalılık, süreklilik ve denge özellerinde ayarlanması olarak ele almıştır. Kapsam ise programın ne içerdiği ile ilgilidir. Ders programı öğrencide meydana gelen davranış değişikliklerini, bu değişimleri gerçekleştirmeye yönelik öğrencinin karşılaşacağı öğretim materyallerini ve yöntemlerini ve amaca ne oranda ulaşıldığını saptamak amacıyla değerlendirme araç ve standartlarını kapsamaktadır (Doğan, 1982, s.10). Buna göre, bu çalışmada programlar kapsam açısından hedefler ${ }^{1}$, içerik, öğretmeöğrenme süreci ve değerlendirme öğelerine göre incelenmiştir.

İçeriğin düzenlemesinde temel ilkeler arasında yer alan aşamalılık ilkesine göre somuttan soyuta, basitten karmaşı̆ga, kolaydan zora, bütünden parçaya ya da parçadan bütüne, günümüzden geçmişe, olaylardan kavrama ve genellemelere, yakın çevreden uzağa doğru bir sıralama vardır (Demirel, 2006, s. 126). İki öğrenme ürününün aşamalılık göstermesi demek, (a) birinin daha önceden öğrenilmemiş olması koşuluyla, diğerinin ötekinden daha kolay bir şekilde öğrenilebilmesi ve (b) birinin öğrenilmesinden sonra, diğerinin öğrenilebilir veya en azından daha kolay öğrenilebilir hale gelmesi demektir (Özçelik, 2014). Ele alınan programlar bu ilkelere göre incelenmiş ve bulgular tablolar halinde sunulmuştur.

Ornstein ve Hunkins (2009), sürekliliğin zaman içerisinde aynı becerilerin tekrar tekrar kullanılacağı anlamını taşıdığına vurgu yapmaktadır. Öğrencilerin, öğrendikleri her bir davranışı daha da geliştirerek genişletmek ve derinleştirmek (Doğanay, 2008, s. 23) anlamına gelen süreklilik ilkesine göre, programlarda belli zaman aralıklarında aynı hedef tekrarlarının yapılıp yapılmadığı incelenmiştir.

Kaynaşıklık ise konu/temalar ile yaşantıların bir bütünlük içinde etkili ve tutarlı bir şekilde sunulması olarak ifade edilebilir. Dikey kaynaşıklık, içeriğin bir seviyeden diğerine

\footnotetext{
${ }^{1}$ MEB tarafından yayımlanan öğretim programlarının bazılarında "kazanım” ifadesi de kullanılmıştır. Ancak çalışmada terim birliği sağlanması açısından "hedef/hedefler" sözcükleri tercih edilmiştir.
} 
ardışıklığını belirtir ve öğrencilerin ders için gerekli hazırlığı yapmasına olanak tanır. Yatay kaynaşıklık ise, mantık ya da konu alanı açısından benzer içeriğe sahip programdaki içeriği harmanlamaya çalışılması demektir (Ornstein ve Hunkins, 2009). Buna göre programların analizinde, program öğeleri arasındaki uyum ve tutarlılık (yatay kaynaşıklık) ile programlar arasındaki uyum ve tutarlılık (dikey kaynaşıklık) incelenmiştir.

Program tasarım ilkelerinin bir diğeri olan denge ilkesine göre, bu özelliğe sahip programlarda, öğrencilerin zihinsel, kişisel, sosyal gelişimlerine uygun olarak öğrendiklerini kullanmalarına ve içselleştirmelerine firsat verilmektedir (Doğanay, 2008, s. 23). Denge program karmaşıklığının öğrencilerin gelişimsel seviyeleri ile uyumlu olması anlamına gelmektedir (Hewitt, 2006). Başka bir deyişle programın dengesi, öğrencinin gelişimine katkıda bulunacak yeterli çeşitlilikte öğretim içeriği ile tanıştırılması olarak tanımlanabilir (Tan, 2011). Bu açıklama 1şığında, programlarda öğrencilerin gelişim özelliklerinin gözetilip gözetilmediğine bakılmıştır.

$\mathrm{Bu}$ tasarım ilkelerinin yanı sıra programlar; temele alınan öğretim yaklaşımı, getirdikleri yenilikler, biçimsel yapıları, kullanışlılık ve esneklik özellikleri açısından da irdelenmiştir. Kullanışlılık ilkesi çerçevesinde programda öğretmenler için ek kaynaklar, iletişim adresleri, maksimum öğrenci sayısı ve gerekli donanım ile ilgili bilgilerin bulunup bulunmadığına bakılmıştır. Esneklik teması altında ise programın bireysel farklılıklara hitap etmesi, farklı duyulara hitap etme, öğretme seçenekleri sunma, özel eğitim ihtiyacı olan öğrencilere uyarlanma, öğretmen özerkliği, öğrenci ve öğretmene yüklediği sorumluluklar açısından incelenmiştir.

Araştırmacılar verilerin analizi ve yorumlanması süreçlerinde işbirliği ve görev paylaşımı yapmışlardır. Ulaşılan öğretim programları öncelikle araştırmacıların iş yükü gözetilerek paylaştırılmış ve bu programlar araştırmacılar tarafından belirlenen ölçütler çerçevesinde bireysel olarak incelenmiştir. Ardından araştırmacılar elde ettikleri bulguları karşılaştırmış ve birlikte yorumlamışlardır. Araştırmacılar sürekli olarak kendilerini ve süreci eleştirel bir gözle sorgulamış ve denetlemişlerdir. Dış geçerliği sağlamak amaciyla araştırmacılar İngilizce öğretim programlarının incelendiği benzer çalışmalara ulaşmış ve elde ettikleri bulguları bu çalışmalarla karşılaştırmıştır.

Araştırmada ilk ve ortaöğretim İngilizce dersi öğretim programlarının seçilmesi, ilk üç yazarın lisans eğitiminin İngilizce öğretmenliği alanında olmasından kaynaklanmaktadır. İlk üç yazarın İngilizce okutmanı olarak ortalama 14 yıllık öğretmenlik deneyimi olması, 
programların analiz edilmesine yardımcı olmuştur. Dördüncü yazarın ise özel okullarda ortaokul ve lise İngilizce öğretmenleriyle program geliştirme çalışmalarına ilişkin tecrübesi bulunmaktadır. Bu deneyimler, araştırmacıların çalışmanın problemine ilişkin konumu ve tutumunu açık olarak ortaya koymasına yardımcı olmuş ve ele alınan programların analizinde büyük kolaylık sağlamıştır.

\section{Bulgular ve Yorum}

Daha önce belirtildiği gibi incelenen İngilizce dersi öğretim programları tasarım ilkeleri olarak kapsam, aşamalılık, süreklilik, kaynaşıklık, denge, kullanışlılık ve esneklik açılarından ele alınmış ve bulgular aşağıda bu başlıklar altında sunulmuştur.

\section{Kapsam}

\section{İlköğretim İngilizce dersi öğretim programlarının kapsam ilkesine uygunluğu.}

İlköğretim 2006 yılı İngilizce Dersi Öğretim Programı ile 4. ve 5. sınıflarda 10 yıl; 6., 7. ve 8. sınıflarda ise 17 yıl aradan sonra değişikliğe gidilmiştir. 4+4+4 eğitim sitemine geçiş ile birlikte 2013 yılı programı, 2. ve 3. sınıfları kapsayacak şekilde yeniden hazırlanmış ve buna bağlı olarak programdaki sürekliliği sağlamada üst sınıfların programları da güncellenmiştir (MEB, 2013, s. ii). Her iki programda da İngilizce öğretiminin amacı, hedefleri, tasarım yaklaşımı ve İngilizce öğretimi ile ilgili genel bilgiler sunulmuş ve ardından sırayla her sınıf düzeyi için hedefler, haftalık ders süreleri, ünite bazında dört temel dil becerisi açısından içerik ve etkinlik türleri verilmiştir. Bu şekilde iki programın da kapsamı net bir şekilde sınırlandırılmıştır. İki programda da genel açıklamalar Türkçe, diğer bölümler ise İngilizce olarak yazılmış ancak, 2013 programında Türkçe çok daha az kullanılmıştır. 244 sayfadan oluşan 2006 programında Seçmeli İngilizce Dersi Öğretim Programı, çalışma yaprakları ve sınav örnekleri de bulunmaktadır. 92 sayfalık 2013 programında ise bunlar kaldırılarak ve genel açıklamalar azaltılarak sadeleşmeye gidilmiştir. Ayrıca, ünite tablolarında kullanılan başlıkların ifade ediliş şekli değişmiştir (Bkz. Tablo 1).

Tablo 1. Yıllara göre ilköğretim İngilizce dersi öğretim programları ünite tablolarında kullanılan başlıklar

\begin{tabular}{ll}
\hline 2006 Yılı & $\mathbf{2 0 1 3 ~ Y ı l ı ~}$ \\
\hline topic (konu) & theme (tema) \\
skills (beceriler) & suggested lexis/ language use (önerilen kelime hazinesi/ dil kullanımı) \\
context (bağlam) & suggested text and activity types (önerilen metin ve etkinlik türleri) \\
functions (dilin işlevleri) & assessment (değerlendirme) \\
tasks (etkinlikler) & projects (projeler) \\
\hline
\end{tabular}


Programların kapsamında hedefler, içerik, eğitim durumları ve ölçme değerlendirme etkinlikleri olmak üzere dört program öğesi de bulunmaktadır. Bu öğelere göre programlar incelendiğinde, sınıf seviyesi yükseldikçe kapsamlarının genişlediği ve buna bağlı olarak haftalık ders sayısının arttı̆̆ı görülmektedir (Bkz. Tablo 2). Bu durumda 2013 yılı programında 5. sınıf için iki saatlik bir artış söz konusudur. Ancak her iki programın da hedefleri ve içeriği göz önünde bulundurulduğunda bu ders saatlerinin yeterli olmadığı düşünülmektedir.

Tablo 2. Yıllara göre ilköğretim İngilizce dersi ögrretim programları haftalık ders saatleri

\begin{tabular}{llc}
\hline Yıl & Sinıf & Haftalık Ders Saati \\
\hline 2006 & 4., 5. sinif & 2 \\
& 6., 7., 8. sinif & 4 \\
2013 & 2., 3., 4. sinif & 2 \\
& 5., 6., 7., 8. sinif & 4 \\
\hline
\end{tabular}

İletişimsel yaklaşımın temele alındığı iki programda da hedefler, öğrencilerin göstermesi beklenen dil yeterlikleri şeklinde verilmiştir. İki programda da hedefler, ağırlıklı olarak bilişsel alandadır ve uygulama basamağına kadar çıkmaktadır. 2006 programında psikomotor alanda az sayıda bulunan hedefler telaffuzla ilgilidir (MEB, 2006, s. 61-200; MEB, 2013, s. 1-77). 2006 yılı programında duyuşsal alana yönelik bir hedefe rastlanmamıştır. Buna rağmen, kullanılması önerilen materyal türleri ve etkinlikler incelendiğinde, öğrencilerin İngilizce öğrenmeye karşı motive olmaları ve olumlu tutum geliştirmeleri için program, öğretmenlere yol göstermektedir (MEB 2006, s. 37-39). 2013 programında ise özellikle 2.,3.,4.,5. ve 6. sınıflarda duyuşsal alana vurgu yapıldığı; “...yabancı dili severek öğrenmektir”, “...esas hedefi dili öğrenen/kullananlarda yabancı dil öğrenme sevgisi oluşturmaktır”, “...yabancı dil sevgisini oluşturmaya devam etmektir”, “...kendine güvenlerini, motivasyonlarını ve İngilizce öğrenmeye karşı olumlu tutumlarını arttırması amaçlanmaktadır”, "İngilizce öğrenmeye olan ilgilerini arttırmak...”, “...dile karşı olumlu bir tutum geliştirmelerine yardımcı olmak" şeklindeki ifadelerden anlaşılmaktadır (MEB, 2013, s. 1, 12, 23, 34, 45).

Her iki programda da içerik olarak temel dil yapıları, dilin işlevleri ve kelime hazinesi ile bu içeriğin verileceği bağlamlar, materyal ve etkinlik türleri bulunmaktadır. Önerilen görsel-işitsel materyaller öğrencilerin ilgisini çekecek ve dinleme, konuşma, okuma ve yazma becerilerinin kazanılmasına yardımcı olacak niteliktedir. Oyunlar, şarkılar, şiirler, el işleri ve drama vb. gibi öğrencilerin derse aktif katılımlarını sağlayacak etkinlik türlerinin seçildiği fark edilmektedir. Ancak öğretme-öğrenme sürecini kolaylaştıracak olan tüm bu materyal çeşitliliği içerisinde etkileşimli bilgisayar oyunları veya internet uygulamaları gibi teknolojik 
araçların kullanımına yer verilmediği dikkat çekmektedir (MEB, 2006, s. 61-233; MEB, 2013, s. 1-77).

Her iki programın değerlendirme boyutunda da sonuç odaklı değerlendirme yaklaşımının yanında ev ödevi, proje ve portfolyo çalışmaları gibi süreç değerlendirme yaklaşımına, öğretmen değerlendirmesi yanında öz ve akran değerlendirmesine de yer verilmektedir. Ancak 2006 yılı programında yalnızca okuma ve yazma becerilerine yönelik hedefleri ölçen kâğıt-kalem sınavı örnekleri bulunurken, 2013 y1lı programında bunların yanında dinleme ve konuşma becerilerinin de değerlendirilmeye katıldığı görülmektedir (MEB, 2006, s. 25, 26, 235-244; MEB, 2013, s. iv, 1-77).

\section{Ortaöğretim İngilizce Dersi Öğretim Programlarının Kapsam İlkesine Uygunluğu.}

İncelenen yıllara ait ortaöğretim İngilizce dersi programlarında her sınıf düzeyi için belirlenen konu/tema sayıları programların kapsamı altında önemli bir unsur olarak ele alınabilir. Ayrıca bu konu/temaların her biri için ayrılan ders saati ile haftalık ders saatleri de programların kapsam ilkesine uygunluğu araştırılırken göz önünde bulundurulmaktadır. Belirtilen y1llara ait programların kapsamı Tablo 3'te verilmiştir.

Tablo 3. Yıllara göre ortaöğretim İngilizce dersi öğretim programının kapsamı

\begin{tabular}{|c|c|c|c|c|}
\hline $\begin{array}{l}\text { İngilizce Dersi } \\
\text { Öğretim Programı }\end{array}$ & Sınıf Düzeyi & $\begin{array}{l}\text { Konu/Tema } \\
\text { Sayısı }\end{array}$ & $\begin{array}{l}\text { Bir Konu/Tema } \\
\text { için Ayrılan Ders } \\
\text { Saati }\end{array}$ & $\begin{array}{l}\text { Haftalık } \\
\text { Ders Saati }\end{array}$ \\
\hline \multirow{4}{*}{2002 y1l1 } & Hazırlık sınıfı & 32 & 9 & 24 \\
\hline & 9. sinif & 30 & 8 & 8 \\
\hline & 10. sinif & 25 & 4 & 4 \\
\hline & 11. sinif & 31 & 4 & 4 \\
\hline \multirow{6}{*}{2014 y1l1 } & 9. $\sin 1 f(A 1 / A 2)$ & 10 & Belirtilmemiş & 6 \\
\hline & 10. $\sin 1 f(A 2+/ B 1)$ & 10 & Belirtilmemiş & 4 \\
\hline & 11. $\sin 1 f(B 1+/ B 2)$ & 10 & Belirtilmemiş & 4 \\
\hline & 12. $\operatorname{sinif}(\mathrm{B} 2+)$ & 10 & Belirtilmemiş & 4 \\
\hline & Hazırlık sinıfi (A1/B1) & 20 & Belirtilmemiş & 20 \\
\hline & 9. $\sin 1 f(B 1 / B 1+)$ & 10 & Belirtilmemiş & 6 \\
\hline \multirow{3}{*}{2016 y1l1 } & 10. $\sin 1 f(B 1+/ B 2)$ & 10 & Belirtilmemiş & 4 \\
\hline & 11. $\sin 1 f(B 2 / B 2+)$ & 10 & Belirtilmemiş & 4 \\
\hline & 12. $\sin 1 f(B 2+/ C 1)$ & 10 & Belirtilmemiş & 4 \\
\hline
\end{tabular}

Tablo 3 incelendiğinde, 2014 ve 2016 programlarında 2002 programına göre konu/tema sayılarında düşüş olduğu görülmektedir. Yıllar içinde haftalık ders saatlerinde sınıf düzeyinde çok büyük bir fark olmamasına rağmen konu/tema sayısındaki bu azalma, birçok dil işlevinin ve içeriğin aynı tema kapsamında öğrencilere sunulmasını temel alan tematik yaklaşımın son y1llardaki programlarda daha çok benimsendiğini göstermektedir. Ancak 2002 programında 
her sınıf düzeyinde konu/tema sayılarının benzer kalmasına rağmen, bunlara ayrılan ders saatlerinin sınıf düzeyi yükseldikçe azalmasının nedeni açıklanmamıştır ve bu durum derslerin uygulanmasında süre ile ilgili problemlerin yaşanması ihtimalini doğurmuştur. Ayrıca 2014 ve 2016 öğretim programları incelendiğinde, birçok açıdan birbirlerine benzer oldukları anlaşılmış ve 2016 programında sadece bazı temalarda değişiklik yapıldığı ve Hazırlık sınıfları için de öğretim programı eklenerek ortaöğretim sınıf düzeylerinin ona göre tekrar hazırlandığı görülmüştür.

2011 yılında ise sınıf düzeyine ya da konu/temalara göre bir öğretim programı oluşturmak yerine Avrupa Ortak Başvuru Metni'nde belirtilen dil düzeylerine uygun hedefler temelinde bir program oluşturulduğu için bu programa ait bilgiler yukarıdaki tabloya eklenememiştir. Bu metinden yola çıkarak öğrencilerin dil yeterlilik düzeyleri ilk defa Temel (A1/A2), Bağımsız (B1/B2) ve Deneyimli (C1/C2) olarak sınıflandırılmıştır. Her bir dil düzeyinin tamamlanabilmesi için gerekli ders saati program metninde tablolar halinde verilmiştir (MEB, 2011, s. 34). Dilbilgisi yapısı ve kurallarının öğrenciye sezdirilerek benimsetilmesi yaklaşımı önerilmiştir. Ayrıca toplam 22 tema ve bu temalara uygun içerikler (konular) önerilmiştir. Tablo 4'te İngilizce dersi öğretim programı çerçevesinde dil yeterlilik düzeylerinde ele alınan tema ve içerik sayıları belirtilmiştir. Bu durum, 2011 yılından itibaren programdaki hedefler ve içeriğin, öğrencilerin dil yeterlilik seviyelerine göre belirlendiğini göstermektedir.

Tablo 4. 2011 İngilizce öğretim programında dil yeterlik düzeyleri, tema sayıları ve içerik sayıları (MEB, 2011)

\begin{tabular}{lll}
\hline Dil Yeterlik Düzeyleri & Tema Sayıları & İçerik Sayları \\
\hline A.1.1 & 6 & 18 \\
A.1.2 & 6 & 18 \\
A.2.1 & 8 & 24 \\
A.2.2 & 8 & 24 \\
A.2.3 & 8 & 24 \\
B.1.1 & 8 & 24 \\
B.1.2 & 8 & 24 \\
B. 2.1 & 10 & 30 \\
B.2.2 & 10 & 30 \\
C.1.1 & - & - \\
\hline
\end{tabular}

Dilin işlevlerine, içeriğe ve sınıf içi etkinliklere ayrılan süre de kapsam ilkesini doğrudan etkilediğinden programlara bu açıdan bakıldığında, 2002 yılında örnek ders planları aracılığıyla her bir konuya/temaya ayrılması gereken ders saatinin belirtilmesine karşın; 2014 ve 2016 yıllarında örnek ders planlarının programlarda yer almadığı görülmektedir. Ayrıca, örnek ders planları incelendiğinde, öğrencilerden beklenen proje çalışmasının ve sınıf içi 
etkinliklerin çok kapsamlı olmasından dolayı bir ünite için haftalık dört ders saatinin (her biri 40 dakika) yeterli olmayabileceği tahmin edilmektedir (MEB, 2002, s. 161-166). Yine örnek ders planında kaç kişilik bir sınıf için bu planın hazırlandığı belirtilmediği için ülke genelinde uygulanırken de süre yetersizliği açısından problemlerin yaşanması muhtemeldir. Aynı şekilde, 2011 programında yer alan örnek ders planında bir ders saati (40 dakika) için 16 hedefe yer verilmiş ve bu hedefler dilin dört becerisinden seçilmiştir. Bireysel ve grup çalışmaları öneren etkinliklerin de yer aldığı plan incelendiğinde, tüm hedeflere belirlenen sürede ulaşılmasının mümkün olmayacağı söylenebilir (MEB, 2011, s. 49-56). 2014 ve 2016 programlarında ise her bir tema için ayrılan sürenin program metninde belirtilmemesine rağmen bu açıdan sorun yaşanmayacağı izlenimi edinilmiştir. Örneğin, 2014 programında 10. sınıf düzeyinde 10 ünite haftalık dört ders saatlik bir düzenlemeyle önerilmiştir (s. 14-23) ve hedeflere belirlenen bu sürede ulaşılabileceği düşünülmektedir.

Programlardaki hedefler daha detaylı incelendiğinde, 2002 programı hedefleri genel hedefler ve dört beceri için detaylı hedefler olmak üzere beş kategoride hazırlanmıştır. Hedeflerin, genel olarak programın hazırlanma gerekçesi olarak belirtilen iletişimsel yaklaşıma uygun olduğu ve öğrencileri günlük hayatlarında dil bilgilerini kullanmaya teşvik ettiği görülmektedir (MEB, 2002, s. 44-46, 90, 91, 120-122, 142-144). Örneğin;

Hazırlık Sinıfi Dinleme Becerisi Hedef 11: Okulda, trafikte, havaalanında, bankada vb. farklı ortamlarda uyulması gereken kuralları dinlediğinde anlayabilmesi.

9. Sınıf Konuşma Becerisi Hedef 3: Kendisi ve bir başkasının güncel yaşamına iliş̧kin bilgi alışverişinde bulunabilmesi.

10. Sinıfi Okuma Becerisi Hedef 7: Okuduğundan edindiği bilgileri yorumlayıp dĕgerlendirebilmesi.

11. Sınıf Yazma Becerisi Hedef 7: Bir yere ve kişiye ilişkin ayrıntılı bilgi alışverişinde yazll olarak bulunabilmesi gibi.

2002 programındaki hedeflerin genellikle bilişsel alana hizmet ettiği, duyuşsal alan için ise her bir becerinin "farklı kültürlerden insanlarla iletişim kurmaya istekli olabilmesi” gibi birer hedef ile örneklendirildiği görülmüştür (MEB, 2002, Hedef 18, s. 44; Hedef 17, s. 45; Hedef 17, s.46; Hedef 11, s. 46). Bilişsel alanla ilgili hedeflerin de bilgi ve kavrama gibi başlangıç düzeyindeki davranışlarla sınırlı kaldığı, üst düzey düşünme becerilerini (analiz, sentez, değerlendirme) pek harekete geçirmediği söylenebilir. "Jest ve mimiklerle anlatılanları tahmin edebilmesi” gibi bilişsel ve psikomotor alana yönelik hedefler de genellikle dinleme ve konuşma becerisi altında yer almaktadır (MEB 2002, Hedef 4, s. 44; Hedef 8, s.45). Genel 
olarak, bilişsel alandan hedeflerin yer aldığı 2011 programında "Konuşmalarında beden dilini kullanır" gibi psikomotor alan hedefleri nadiren de olsa yer almaktadır, ancak duyuşsal alana dair hedeflere rastlanamamıştır (s. 74). 2014 ve 2016 programlarında ise öncekilerden farklı olarak hedefler, her sınıf düzeyi için belirlenen becerilerin altında verilmiştir. $\mathrm{Bu}$ yıllarda diğer yıllarda olduğu gibi dört becerinin birbirini tamamlayıcı olarak kullanılması gerektiği vurgulanmış ve dört beceriye ek olarak her temada telaffuzla ilgili hedeflere ayrı olarak değinilmiştir. Telaffuz bölümlerinde bulunan "Öğrenci kelime vurgusunu telaffuz edebilir" (MEB, 2016, s. 49), “Öğrenciler had ve would yapılarının kısaltılmış biçimlerini pratik edebilir" (MEB, 2014, s. 28) gibi hedef örnekleri psikomotor alanın bu programlarda daha çok yer almaya başladığını göstermektedir. Önceki yıllara ait programlarda üst düzey bilişsel alan hedeflerine pek rastlanmadığ görülmesine rağmen, 2014 ve 2016 yıllarına ait öğretim programlarında öğrencilerin artan dil düzeyiyle uyumlu olarak üst düzey bilişsel becerilere yönelik hedeflere de rastlanmaktadır:

“Öğrenciler tercihlerini nedenleriyle beraber tartışabilir” (MEB, 2016, s. 34)

“Öğrenciler medya mesajlarını analiz edebilir” (MEB, 2016, s.40)

2014 ve 2016 programlarında da önceki programlara benzer şekilde duyuşsal alana ait hedeflere pek rastlanmamakta, sadece "Öğrenciler konuşmalarında memnuniyetsizliklerini ifade edebilir” (MEB, 2016, s.66) gibi birkaç örnek dikkat çekmektedir.

Programlar hedeflerin açık ve anlaşılır olması açısından incelendiğinde, 2002 programındaki hedeflerin bazen bu özelliğe sahip olmadığı görülmektedir. Örneğin, konuşma becerisi ile ilgili hedeflere bakıldığında, "Dili sınıf içinde beklenen düzeyde uygun biçimde kullanabilmesi" ifadesinde beklenen düzeyin belirtilmediği ve bunun nasıl gerçekleşeceğinin açıklanmadığı söylenebilir (MEB, 2002, s. 45). 2002 programına benzer olarak 2011 programında da Avrupa Konseyinin belirlemiş olduğu A1, A2 ve B1 dil seviyelerinde belirtilen hedefler açık ve net bir şekilde ifade edilmemiştir. Örneğin, "akıcı konuşur”, "kısa, basit hikâyeler okur", "kısa metinler yazar" gibi hedef ifadeleri anlaşılır değildir ve yeterince detaylandırılmamıştır. Ancak 2014 ve 2016 programlarındaki "Öğrenciler günlük yaşamda karşılarına çıkan nesnelerle ve alışverişle ilgili kelimelerin yazılışlarını ayırt edebilir” gibi hedef ifadeleri daha net, tutarlı ve anlaşılabilir düzeydedir (MEB 2014, s. 4). 


\section{Așamalılık}

\section{İlköğretim İngilizce dersi öğretim programlarının aşamalılık ilkesine uygunluğu.}

2006 ve 2013 programları en alt sınıftan en üst sınıfa doğru incelendiğinde içeriğin kolaydan zora, basitten karmaşığa, somuttan soyuta, bilinenden bilinmeyene, ön koşul ilkelerine göre sıralandığı görülmektedir (Bkz. Tablo 5). Ayrıca 2013 programında 2. ve 3. sınıflarda yalnızca dinleme ve konuşma becerilerine önem verilmesi, üst sınıflara gidildikçe diğer dil becerilerinin ilave edilmesi ve buna bağlı olarak hedef sayılarının arttırılması da program tasarımında aşamalılık ilkesine uyulduğunu işaret etmektedir (MEB, 2013, s. iii, v).

Tablo 5. İlköğretim İngilizce dersi ögrretim programlarında aşamalılık ilkesi açısından içerik örnekleri

\begin{tabular}{ll}
\hline 4. Sınıf Düzeyi & 8. Sınıf Düzeyi \\
Ünite 1 (MEB 2006) & Ünite 1 (MEB 2006) \\
\hline Bilgi sorma ve verme & Yönerge vermek ve insanları yönlendirmek \\
Selamlaşma ve kendini tanıtma (s.63) & Tavsiyede bulunmak \\
& Soruşturmak ve bir şeyin ne kadar belirli/belirsiz \\
& olduğunu ifade etmek \\
& Görüşleri bildirmek ve seçim yapmak \\
& Beklentileri soruşturmak ve ifade etmek \\
& Bireysel özellikleri tanımlamak \\
& Alışkanliklar hakkında sormak ve konuşmak \\
& (s. 203) \\
\hline 2. Sınıf Düzeyi & 8. Sınıf Düzeyi \\
Ünite 1 (MEB 2013) & Ünite 1 (MEB 2013) \\
\hline İnsanlara bildiğimizi söylemek (s. 2) & Kabul etmek ve reddetmek \\
& Özür dilemek \\
& Açıklamalarda bulunmak/neden göstermek \\
& Basit soruşturmalar yapmak \\
& Saatleri, günleri ve tarihleri söylemek (s. 68) \\
\hline
\end{tabular}

Ortaöğretim İngilizce Dersi Öğretim Programlarının Aşamalılık İlkesine Uygunluğu.

2002, 2014 ve 2016 programları, Hazırlık sınıfından 12. sınıfa doğru (dikey) ve her sınıf düzeyinde kendi içinde (yatay) incelendiğinde; bilinenden bilinmeyene, yakından uzağa, somuttan soyuta, basitten karmaşığa doğru belli bir sıraya göre düzenlendiği görülmektedir. Öğrencilerin başlangıç düzeyinde temel bilgiler ve kavramlara maruz bırakılması, ayrıntıların ise daha üst seviyelerde öğrenciye sunulması, programda aşamalılık unsurunun göz önünde bulundurulduğuna örnektir. 2011 programında ise diğer yıllar gibi temaları, dil işlevlerini gösteren bir program oluşturmak yerine Avrupa Ortak Başvuru Metni’ndeki dil düzeylerine 
uygun hedefler aracılığıyla bir program oluşturulduğu için aşamalılık ilkesine yönelik örnekler net bir şekilde anlaşılamamaktadır. Bu yüzden de Tablo 6'da yer almamaktadır.

Tablo 6. Ortaöğretim İngilizce dersi öğretim programlarının aşamalılı ilkesine uygunluğuna dair hedef örnekleri

\begin{tabular}{|c|c|c|}
\hline & $\begin{array}{l}\text { 10. Sinıf Düzeyi } \\
\text { Tema } 1 \text { (MEB 2002) }\end{array}$ & $\begin{array}{l}\text { 10. Sınıf Düzeyi } \\
\text { Tema } 24 \text { (MEB 2002) }\end{array}$ \\
\hline Hedef & $\begin{array}{l}\text { Sosyal yaşama ilişkin bilgi alışverişinde } \\
\text { bulunabilmesi (s. 120) }\end{array}$ & $\begin{array}{l}\text { Çevresindeki olay, durum ve koşullara ilişkin } \\
\text { bilgi alışverişinde bulunabilmesi } \\
\text { Bildiği ya da ilgilendiği konularda düşüncelerini } \\
\text { savunup tartışmalara katılabilmesi (s. 120, 121) }\end{array}$ \\
\hline \multirow[t]{2}{*}{$\begin{array}{l}\text { Dil } \\
\text { İşlevleri }\end{array}$} & $\begin{array}{l}\text { Boş zaman aktiviteleri hakkında bilgi vermek } \\
\text { Alışkanlıkları ile ilgili bilgi vermek } \\
\text { Giyim tarzlarını tanımlamak } \\
\text { Çeşitli yemek türlerini tanımlamak (s. 123) }\end{array}$ & $\begin{array}{l}\text { Sağlıklı bir diyet hakkındaki fikirlerini ifade } \\
\text { etmek } \\
\text { Sağlık önlemleri ile ilgili fikirlerini ifade etmek } \\
\text { Yiyecek ve sağlıkla ilgili tavsiye vermek (s. 131) }\end{array}$ \\
\hline & $\begin{array}{l}\text { Hazırlık Sınıfı Düzeyi } \\
\text { Tema } 1 \text { (MEB 2002) }\end{array}$ & $\begin{array}{l}\text { 11. Sinıf Düzeyi } \\
\text { Tema } 1 \text { (MEB 2002) }\end{array}$ \\
\hline Hedef & $\begin{array}{l}\text { Kendisinin ve bir başkasının güncel yaşamına } \\
\text { ilişkin bilgi alışverişinde bulunabilmesi ( } \mathrm{s} \text {. } \\
\text { 45) }\end{array}$ & $\begin{array}{l}\text { İnsan ilişkileri hakkında bilgi alışverişinde } \\
\text { bulunabilmesi (s. 142) }\end{array}$ \\
\hline \multirow[t]{2}{*}{ İşlevleri } & $\begin{array}{l}\text { Kendini tanıtma } \\
\text { Selamlaşma } \\
\text { Kişisel bilgi sorma ve verme } \\
\text { Sinıf talimatlarını anlama ve uygulama } \\
\text { Uluslar, adresler ve telefon numaralarıyla } \\
\text { ilgili bilgi sorma ve verme (s. } 47 \text { ) }\end{array}$ & $\begin{array}{l}\text { Kişisel problemlerini ifade etmek } \\
\text { Aile ve arkadaşlarıyla ilişkisi hakkında bilgi } \\
\text { vermek } \\
\text { Kişisel problemlere çözüm önermek } \\
\text { Değişik duygu durumlarını açıklayabilme (s. 145) }\end{array}$ \\
\hline & $\begin{array}{l}\text { 9. Sınıf Düzeyi } \\
\text { Tema } 1 \text { (MEB, 2014) }\end{array}$ & $\begin{array}{l}\text { 9. Sınıf Düzeyi } \\
\text { Tema } 10 \text { (MEB, 2014) }\end{array}$ \\
\hline Hedef & $\begin{array}{l}\text { Öğrenciler mesleklerle, ülke ve dillerle alakalı } \\
\text { kelimeleri ayırt edebilir ve dinleyebilir. } \\
\text { Öğrenciler kendilerini ve aile üyelerini } \\
\text { tanıtabilir. } \\
\text { Öğrenciler kişisel eşyaları hakkında } \\
\text { konuşabilir. } \\
\text { Öğrenciler posta kartları ve selamlama } \\
\text { kartlarındaki temel ifadelerin ve kelimelerin } \\
\text { farkına varabilir(s. 3) }\end{array}$ & $\begin{array}{l}\text { Öğrenciler kendileriyle ilgili genişletilmiş } \\
\text { tartışmaların ana noktalarını takip edebilir. } \\
\text { Öğrenciler diğer öğrencilere katılabilir veya } \\
\text { katılmayabilir. } \\
\text { Öğrenciler olaylar ve nesneler hakkında ne } \\
\text { düşündüklerini söyleyebilir (s. 12). }\end{array}$ \\
\hline $\begin{array}{l}\text { Dil } \\
\text { İşlevleri }\end{array}$ & $\begin{array}{l}\text { Kendini ve ailesini tanıtma } \\
\text { Eşyaları hakkında konuşma } \\
\text { Yeni insanlarla tanışma } \\
\text { Meslekler hakkında konuşma } \\
\text { Değişik ülkeleri ve dilleri isimlendirme } \\
\text { (s.3) }\end{array}$ & $\begin{array}{l}\text { Gelecek hakkında yorumda bulunma } \\
\text { Katılma, katılmama ifadelerini kullanma } \\
\text { Düşünce sorma } \\
\text { Diyalogda birinin sözünü kesme } \\
\text { Diyalogda zaman kazanma (s.12) }\end{array}$ \\
\hline & $\begin{array}{l}\text { Hazırlık Sınıfı Düzeyi } \\
\text { Tema } 1 \text { (MEB 2016) }\end{array}$ & $\begin{array}{l}\text { 12. Sınıf Düzeyi } \\
\text { Tema } 1 \text { (MEB 2016) }\end{array}$ \\
\hline Hedef & $\begin{array}{l}\text { Öğrenciler tanışma ve diyaloglarda sık } \\
\text { kullanılan kelimeleri ayırt edebilir. } \\
\text { Öğrencilerle mesleklerle ilgili konuşabilir. } \\
\text { Öğrenciler okuma parçasında geçen kişilere } \\
\text { ait ülke, ulus ve dil isimlerini ayırt edebilir. } \\
\text { Öğrenciler aile ağacı çizebilir (s. } 31 \text { ). }\end{array}$ & $\begin{array}{l}\text { Öğrenciler iş başvurusu aşamaları için bir } \\
\text { uzmanın tavsiyelerini not alabilir. } \\
\text { Öğrenciler okuma yaparken bir kariyer testini } \\
\text { tamamlayabilir. } \\
\text { Öğrenciler insanları teşvik eden ifadeleri } \\
\text { kullanabilir (s. } 85 \text { ). }\end{array}$ \\
\hline $\begin{array}{l}\text { Dil } \\
\text { İşlevleri }\end{array}$ & $\begin{array}{l}\text { Kendisini ve ailesini tanıtma } \\
\text { Yeni insanlarla tanışma } \\
\text { Meslekler hakkında konuşma } \\
\text { Farklı ulus, devlet ve dilleri isimlendirme } \\
\text { (s.31) }\end{array}$ & $\begin{array}{l}\text { Gelecek planları hakkında konuşma } \\
\text { İnsanları teşvik etmek } \\
\text { Anladığını onaylama } \\
\text { (s. 85) }\end{array}$ \\
\hline
\end{tabular}


Tablo 6'da görüldüğü üzere, hedefler ve dil işlevleri aynı sınıf düzeyinde giderek derinleşen ve genişleyen şekilde verilmiştir. Ayrıca yıllar içinde sınıf düzeyleri incelendiğinde, hedef ve konuların aynı şekilde derinleşip genişleyerek yıllara dağıldığı görülmektedir. Sonraki yıllarda hazırlanan programlarda da dil ediniminde yeni yaşantıları geçirmek için ilgili önkoşul davranışların kazanılmış olması gerekliliği göz önünde bulundurulduğundan, hedefler ve içeriğin sarmal bir yaklaşımla A1 düzeyinden $\mathrm{C} 1$ düzeyine doğru genişletilerek oluşturulduğu görülmektedir. Ayrıca 2014 ve 2016 programlarında hedeflerin ilgili tema ve dil işlevleriyle beraber öğretim programlarının içinde sunulması ile programın bilinenden bilinmeyene, basitten zora olma durumu ve dil seviyesinin sinif düzeyine göre ilerlemesi daha anlaş1lır ve belirgin hale gelmiştir. 2014 ve 2016 programları benzer özellik taşıdığından aynı sınıf düzeyindeki aşamalılık ilkesi ve sınıf düzeyleri arası aşamalılık ilkesi birer örnekle açıklanmıştır.

\section{Süreklilik}

\section{İlköğretim İngilizce dersi öğretim programlarının süreklilik ilkesine uygunluğu.}

2006 ve 2013 programları kapsamında üst sınıflara doğru çıkıldıkça alt sınıflardaki dil becerilerinin, dil işlevlerinin, dil yapılarının ve kelimelerin tekrar edilerek genişletildiği görülmektedir (Bkz. Tablo 7). Ayrıca 2006 programının sarmal biçimde hazırlandığı, 2013 programının da öğrencilerin önceki bilgilerini tekrar hatırlayarak üzerine yeni bilgileri inşa edecekleri şekilde tasarlandığına dair açıklamalar yapılmıştır (MEB, 2006, s. 2; MEB, 2013, s. iv).

Tablo 7. İlköğretim İngilizce dersi ögrretim programlarında süreklilik ilkesine dair içerik örnekleri

\begin{tabular}{ll}
\hline 7. Sınıf Düzeyi (MEB, 2006) & Üniteler \\
\hline Gerçek bilgi vermek ve aramak & $1,2,8,14,15$ \\
$\begin{array}{l}\text { Bilgi vermek ve aramak } \\
\text { Kiyaslama yapmak ve farklılık derecelerini }\end{array}$ & $3,4,5,9,10,11,12$ \\
bildirmek & $4,5,13,14,15$ \\
Geçmiş olayları tanımlamak ve anlatmak & $8,9,10$ \\
\hline 7. Sınıf Düzeyi (MEB, 2013) & \\
\hline Açıklamalar yapmak/nedenler sunmak & $1,2,3,4,5,8,9$ \\
Basit karşılaştırmalar yapmak & 1,10 \\
Basit soruşturmalar yapmak & $1,2,3,4,5,7$, \\
Geçmiş olaylar hakkında konuşmak & $2,3,4,5,8,10$ \\
Olayların sıklığını tanımlamak & 3,4, \\
İnsanların düzenli olarak yaptığı şeyleri anlatmak & $3,5,8$ \\
Saatleri, günleri ve tarihleri söylemek & 2,10 \\
Basit önerilerde bulunmak & $4,6,7,8$ \\
İnsanlara bildiğimizi anlatmak & 3,10 \\
\hline
\end{tabular}


Ortaöğretim İngilizce dersi öğretim programlarının süreklilik ilkesine uygunluğu.

Aynı işlevlerin farklı konular ve dil yapılarıyla verilmesi programda süreklilik ilkesine hizmet ettiğinden, 2002 programı için bu ilkenin göz önünde bulundurulduğu söylenebilir. Örneğin, Hazırlık sınıfı programında 12.konuda ayrıntılı olarak ele alınan "geçmiş olayları ifade etme" (s. 59) dil işlevinin, 9. sınıfın 2.konusunda (s. 92) farklı bir bağlamda öğrencilerin karşısına tekrar çıkarılması planlanmıştır. Buna ek olarak, yine aynı programda 9.sınıf düzeyinde 6 . konuda yer alan "insanları ve nesneleri karşılaştırma” (s. 94) dil işlevi, 9. sınıfta 13. konuda “ergenler için mesleklerin karşılaştırılması" (s. 98); 25. konuda yer alan "Türkiye ve yurtdışındaki yerleşim yerlerini karşılaştırma” (s. 104), 10. sınıf düzeyinde 11. konuda "kasaba ve ülkeleri karşılaştırma” (s.127), “Avrupa ve Türk kültüründeki gelenekleri karşılaştırma" (s. 127) ve 11. sınıf düzeyinde de 2. konuda "televizyondaki ve sahnedeki performansı karşılaştırma" (s. 145) olarak çeşitli bölümlerde karşımıza çıkmaktadır. Bu durum; hem sınıf düzeyleri arasında hem de aynı sınıfın konuları arasında dil işlevlerinin sık sık genişleyerek tekrar edildiğini ve süreklilik ilkesinin benimsendiğini örneklendirmektedir.

2014 ve 2016 yıllarına ait programlar incelendiğinde dil işlevlerinin birçoğunun daha sonraki dil düzeylerinde ve sınıflarda farklı temalar altında ele alındığına dair örnekler mevcuttur. Örneğin; 2014 yılında "tavsiye vermek" dil işlevi ilk olarak A1 seviyesinde 9.sınıfta "acil ve sağlık problemleri” temasında öğrencilere sunulurken, aynı tema A2 düzeyinde 10.sınıfta "yararlı öneriler" temasında ve B1 düzeyinde 11.sınıfta "kalbini aç" temasında ele alınmış ve aynı işlev farklı sınıflarda ve farklı dil seviyelerinde tekrar öğrencilerin karşısına çıkarılmıştır (MEB, 2014, s. 10, 19, 30). Benzer şekilde 2016 programında "kişisel bilgi sorma ve verme" dil işlevi Hazırlık sınıfında A1 seviyesinde "yurtdışında okuma" temasında sunulurken, 9.sınıf B1 düzeyinde "boş zamanlarda" teması altında tekrar ele alınmıştır (MEB, 2016, s. 31, 52). Yine B1 düzeyinde 9.sınıfta "boş zamanlarda" teması altında verilen "hobiler hakkında konuşma" işlevi Hazırlık sınıfında A1 düzeyinde "sinemalar" teması altında sunulmuştur (MEB, 2016, s. 33, 52). Tüm bu düzenli ve anlaşılır örnekler; 2014 ve 2016 yıllarında süreklilik ilkesinin programlarda yer aldığını göstermektedir. Zaten süreklilik ilkesi olarak isimlendirilmese de bu görüş; açıklamalar kısmında dil işlevlerinin farklı bağlamlarda pekiştirme amaçlı ele alındığı şeklinde belirtilmiş ve özellikle de Hazırlık sınıfında ders programının yoğun olması nedeniyle tekrarların fazla olduğu bir programın bilinçli olarak tercih edildiğinden bahsedilmiştir (MEB, 2016, s. 29). 


\section{Kaynaşıklık}

\section{İlköğretim İngilizce dersi öğretim programlarının kaynaşıklık ilkesine uygunluğu.}

2006 ve 2013 programları incelendiğinde amaç, hedefler, dil becerileri, yapıları, işlevleri ve önerilen materyal türleri, verilen etkinlik örneklerinin genel olarak birbiriyle örtüştüğü fark edilmektedir. Ayrıca her iki programda da kazandırılmaya çalışılan temel dil becerileri ve bunlara önerilen dil yapıları ve işlevleri, temel düzey İngilizce öğrenen bir kişinin günlük hayatta iletişim kurabilmesini sağlayacak niteliktedir. Bu bağlamda, iki programın da günlük hayatta kullanılan dille de ilişkili olduğu görülmektedir. Bununla ilgili olarak 2013 programında dil öğreniminin günlük hayatla ilişkilendirilmesi için aile, arkadaşlar, hayvanlar, tatil vb. gibi genç öğrencilere tanıdık gelen temaların seçildiği belirtilmiştir. Konuyla ilgili bir diğer açıklama da materyallerin İngilizcenin gerçek hayatta kullanıldığg ş̧eklini yansıtan, otantik kaynaklardan alındığıdır (MEB, 2013, s. iii, iv). Ancak, kaynaşıklık ilkesine ters düşen bir nokta; 2006 programının ölçme ve değerlendirme boyutunun yalnızca okuma ve yazma becerilerine yönelik olması, dinleme ve konuşma becerilerini ölçen sorulara yer verilmemesidir (MEB, 2006, s. 235-244).

\section{Ortaöğretim İngilizce dersi öğretim programlarının kaynaşıklık ilkesine} uygunluğu.

Programın öğelerinin kendi içlerindeki uyum ve tutarlılığı ile bunların dört ana beceri ile uyum ve tutarlılığının incelendiği kaynaşıklık ilkesine göre, 2002 programında bu becerilerin tek tek ele alındığı görülmüştür ki, bu durum programın bütünlüğünü olumsuz etkilemektedir. Öğrencilerin hedeflenen dil yapısına dilin dört ana becerisi kapsamında maruz bırakılmamasının öğrenmeleri zorlaştıracağı öngörülmektedir. Programda ölçme ve değerlendirme öğesinin altında yer alan başarı testleri, izleme testleri, öğrencilerin sınıf içi yazılı ve sözlü proje sunumları, ikili ve grup tartışmalarına öğrencinin etkin katılımı, görselişitsel araçları düzenli kullanma ve yabancı dile gösterdiği tutum ve davranışlarında gösterdiği gelişme gibi ölçütler, değerlendirmenin sürece yayılması gerektiğini göstermekte (s. 33) ve benimsenen iletişimsel yaklaşım ile tutarlı olduğu görülmektedir. Ancak her bir beceri için soru örneklerinin paylaşıldığı ve hedeflerle uyumlu olarak ne tür soruların hazırlanacağını gösteren değerlendirme bölümüyle ilgili örnek sorular incelendiğinde, hedeflenen kelime ve dilbilgisi yapılarının bağlamdan uzak bir şekilde test edildiği anlaşılmaktadır. Bu durum, iletişimsel yaklaşım ve dil işlevlerinin doğal ortamda öğretilmesi ve değerlendirilmesi anlayışıyla uyuşmamaktadır. Örneğin; 9. sınıf düzeyi için verilen sıfatların pozitif ya da 
negatif anlam içermesine göre sınıflandırılmasını isteyen soru örneği, hem bağlamdan yoksun hem de işlevsellikten uzaktır (MEB, 2002, s. 118).

2011 programında ise ölçme ve değerlendirme başlığı altında performansa dayalı ve süreç odaklı bir yaklaşımın benimsenmesi gerektiği önerilmiş ve içeriği detaylı bir şekilde açıklanmıştır (s. 27-39). Ancak programda hedefler ilgili dil işlevleriyle, etkinlik ve ölçmedeğerlendirme yöntemleriyle bir bütünlük oluşturacak şekilde sunulmadığı için bahsedilen ölçme-değerlendirme yaklaşımının nasıl uygulanacağı belirsiz kalmıştır. Bu durum da programın kendi içinde tutarlı olma özelliği konusunda eksiklerinin olduğunu göstermektedir.

Kaynaşıklık ilkesinin altında dilin dört becerisi arasındaki ilişkiye bakıldığında; 2011, 2014 ve 2016 programlarında 2002 programının aksine dört becerinin beraber ele alınmasını öneren bir yaklaşım benimsendiği görülmektedir. 2014 ve 2016 programlarında hedeflerin ve ilgili işlevlerin yer aldığı tablolarda materyaller ve etkinlikler de önerilmiştir. Teknolojik donanımlar olan Eğitim Bilişim Ağı (EBA), video blog gibi materyallerden her temada yararlanılmasının önerilmesiyle birlikte rol yapma, bilgi boşluğu tamamlama, tartışma, sözlü sunum, jigsaw gibi çeşitli etkinliklerin de işe koşulduğu görülmektedir. Bu durum, programın dört ana öğesinin birbirini desteklediğine ve tutarlı yönde olduğuna örnektir. Ayrıca önerilen materyal ve etkinliklerin programların giriş bölümlerinde açıklanan teknoloji desteğinin, iletişimsel yaklaşım ve öğrenen özerkliği gibi birçok kavramla uyumlu olduğu da söylenebilir.

2014 ve 2016 programlarındaki temalar ve dil işlevleri incelendiğinde, günlük hayata ilişkin dil işlevleri bir bütün olarak ele alındığından kaynaşıklık ilkesinin göz önünde bulundurulduğu söylenebilir. Bu programlarda ilköğretim programlarının aksine, program çeşitli seviyelere bölünmemiş ve katı sınırların olmadığı bir sınıflar arası öğretim anlayışı benimsenmiştir. $\mathrm{Bu}$ yıllarda değerlendirme araçlarının performansa ve geleneksel ölçme yöntemlerine dayalı olması gerektiği belirtilmiştir. Örneğin daha önceki yıllarda belirtilmeyen rubric, Tech-paper, e-portfolio gibi değerlendirme türlerinin yanı sıra önerilen iletişimsel yaklaşımla çok bağdaştırılamayacak kalem kâğıt testleri de yer almaktadır.

\section{Denge}

\section{İlköğretim İngilizce dersi öğretim programlarının denge ilkesine uygunluğu.}

2006 ve 2013 y1lı programlarının hedef kitledeki öğrencilerin gelişim özelliklerine uygun olarak tasarlanmaya çalışıldığı anlaşılmaktadır. Örneğin 2006 programında öğrencilerin gelişim özellikleri ve buna göre nasıl öğrendikleri detaylı bir şekilde anlatılarak, uygun 
materyal ve etkinlik türleri önerilmiştir (MEB, 2006, s. 38, 41-61, 199-122, 239-244). Hedeflerde yer alan "basit", "temel”, "sınırlı", "tanıdık" ve "kısa” gibi ifadelerin kullanılması, İngilizce öğrenmeye yeni başlayan öğrencilerin ulaşabileceği düzeyde hedefler konulduğunun göstergesidir. Programda alt sınıflar için verilen örnek sınavların kısa ve basit cümlelerden ve sorulardan oluşması, daha çok resim içermesi, üst sınıflardakilerde ise daha az resim ve daha çok yazı bulunması da öğrencilerin gelişim özelliklerinin gözetildiğini kanıtlamaktadır (MEB, 2006, s. 235-244).

2013 programında öğrencilerin gelişim özellikleri, 2006 programındaki gibi detaylı bir şekilde verilmiş olmasa da her sınıf seviyesi için uygun türde etkinliklerin sunulduğu, farklı gelişim evrelerinde olan öğrencilerin ihtiyaçlarını karşılayacak şekilde İngilizce öğretiminin eğlenceli ve çekici hale getirmenin amaçlandığı ifade edilmiştir. Bunun yanında, programın 2., 3. ve 4. sınıflar için oyun temelli olarak tasarlandığı belirtilmektedir. Ayrıca, hedeflerin Avrupa Ortak Dil Çerçevesinde temel dil düzeyi belirleyicisi olan A1 ve A2 düzeylerindeki dil yeterlik tanımlarına uygun olarak hazırlanması, öğrencilerin dil düzeylerine dikkat edildiğini göstermektedir (MEB, 2013, s. iii, v, vi, 1, 12, 23).

\section{Ortaöğretim İngilizce dersi öğretim programlarının denge ilkesine uygunluğu.}

2002, 2014 ve 2016 programlarının hedefleri ve konu/temaları incelendiğinde öğrencilerin hem yaş hem de dil seviyelerinin gözetilerek gelişim düzeylerine uygun bir program hazırlandığı, dolayısıyla denge unsurunun göz önünde bulundurulduğu görülmektedir. Ancak 2011 programında dil düzeylerine göre hedeflerin açıklanmasına dayanılarak, gelişim özelliklerinin değil; dil yeterlilik düzeylerinin temel alındığı söylenebilir.

2002 programında sınıf düzeylerinde ele alınan konular öğrencilerin zihinsel ve dil gelişimleriyle uyumlu olarak yıllar içinde derinleşmiş ve ilgi ve ihtiyaçlarına yönelik düzenlenmiştir. Örneğin; Hazırlık sınıf düzeyinde aile, çevre, boş zaman aktiviteleri, geleceğe yönelik planlar gibi konular yer alırken, 11. sınıf düzeyinde stres, meslekler, bilgisayar, evlilik ve para gibi konular yer almıştır.

2014 ve 2016 programlarında da öğrencilerin zihinsel gelişim düzeylerinin; bilişsel, duyuşsal ve psikomotor becerilerinin ve çalışma alışkanlıklarının göz önünde bulundurularak konu/tema ve hedeflerin belirlendiği görülmektedir. Öğrencilerin yaş ve gelişim özelliklerinin dikkate alındığ 1 programlarda, rekabet yerine işbirliğine dayalı bir sınıf ortamının yaratılması, öğrenen özerkliğinin sağlanması, proje temelli etkinliklerin düzenlenmesi önerilmiştir ve 
gerekçe olarak da bu yaş grubundaki öğrenciler için arkadaşlarına bağlılık, keşif ve özerklik gibi kavramların önemli olduğu vurgulanmıştır (MEB, 2016, s. 5). Ayrıca, tema ve etkinlik seçimlerinde öğrencilerin gelişimsel özelliklerine ve yaşlarına uygun, ilgi ve ihtiyaçlarına önem verilerek bir program oluşturulduğuna dair bulgular vardır. Örneğin 2016 yılında 12. sınıf düzeyi için hazırlanan programda iş bulma, bütçe yönetme, sınav kaygısı, kariyer testi gibi tema ve işlevlerin ele alınması öğrencilerin lise bitirme aşamasındaki ihtiyaçlarından kaynaklanmaktadır. Yenilenebilir enerji, batıl inançlar, göç ve afetler gibi toplumsal olayların ve soyut kavramların programda yer alması da 12. sınıf düzeyindeki öğrencilerin zihinsel ve dil gelişim düzeylerinin göz önüne alındığını göstermektedir. Yine 12. sınıf düzeyinde B2+/C1 dil düzeyindeki programın akademik becerileri kazandırma hedefini içermesi öğrencilerin bilişsel olarak hazır olması ve üniversite öncesi ihtiyaçları ile açıklanabilir (MEB, 2016, s. 84-94). 10. sınıf düzeyinde seçilen nesil farkı ve 9. sınıf düzeyinde seçilen okul zorbalığl ve $Z$ nesli gibi tema ve dil işlevleri de öğrencilerin ilgili yaş döneminde yaşadıkları zihinsel ve sosyal durumlarıyla ilişskilidir (MEB, 2016, s. 58, 67).

\section{Kullanışlılık ve Esneklik}

İlköğretim İngilizce dersi öğretim programlarının kullanışlılık ve esneklik ilkelerine uygunluğu.

Programlarda kullanılan dilin açık ve anlaşılır olması, biçimsel yapılarındaki tutarlılık; onları kolay okunabilir ve takip edilebilir dokümanlar haline getirmiştir. Bu anlamda her iki programın da kullanışlı olduğu söylenebilir. Ayrıca programların TTKB'nin resmi internet sayfasında dijital formatta bulunması da ulaşabilirlik açısından kullanışlılık niteliğini arttırmaktadır. Bunun dışında, 2006 programı oldukça yoğun iken 2013 programının sadeleştirilmiş olması, kullanışlılık açısından bir iyileştirmeye gidildiğini düşündürmektedir.

Programlar esneklik açısından incelendiklerinde, 2006 programında hedef dilin öğretilebileceği çeşitli bağlamlar, etkinlik ve materyal türlerinin önerildiği görülmektedir. Öğretmenin bunlar arasından seçim yapabilmesi önerildiğinden programın öğretmen özerkliğini kısmen desteklediği söylenebilir. Ancak 2013 programı öğretmene değerlendirme boyutu dışında böyle bir seçim yapma olanağı sunmamaktadır. Her iki programda da sunulan materyal ve etkinlik çeşitliliği, farklı zekâ alanlarına ve öğrenme stillerine sahip öğrencilere hitap etme konusunda öğretmene yardımcı olabilir. Bunun yanında, programlarda yer alan “Ülkem”, "Diğer Ülkeler", "Başkentler" (MEB, 2006), "Çocuk Bayramı" ve "Festivaller" temaları (MEB, 2013, s. iv, 25, 44), öğrencilerin kültürel çeşitliliğe karşı olumlu tutum geliştirmesini sağlamak amacıyla seçilmiştir. Ancak dinleme, konuşma ve yazmaya dayalı 
olarak iki dil programında da engelli öğrencilerin durumuyla ilgili herhangi bir açıklamaya rastlanılmamaktadır. Ayrıca bu programların kaç kişilik sınıflarda uygulanabileceği, kalabalık sınıflarda ne yapılacağı ya da programın uygulanması için gerekli olan fiziksel şartlar ve donanım konularıyla ilgili bir bilgi verilmemiştir. Esneklik konusunda programlardaki diğer eksiklik ise öğretmenlerin başvurabilecekleri kitap, internet sayfası vb. gibi ek kaynakların sunulmamış olmamasıdır.

\section{Ortaöğretim İngilizce dersi öğretim programlarının kullanışlılık ve esneklik} ilkelerine uygunluğu.

2002, 2011, 2014 ve 2016 programlarının esneklik ve kullanışlılık ilkelerine bazı açılardan uygun olmasına rağmen bazı eksikliklerinin de olduğu görülmektedir. Örneğin, 168 sayfa olarak hazırlanan 2002 öğretim programı incelendiğinde giriş ve temel alınan ilkeler ile programın dört öğesinin açıklanmasının, örnek ders işlenişinin ve örnek ölçme-değerlendirme soruları açıklamalarının Türkçe olduğu, ancak öğretim programı bölümlerinin İngilizce sunulduğu görülmüştür. Programın uygulanması sürecinde Türkçenin ancak gerekli durumlarda kullanılması önerilmiş ve öğrencilerin İngilizce dilini kullanması teşvik edilmiştir. 2002 programında öğretmenlerden ders materyallerinde çeşitlilik sağlayarak öğrencilerin dile görsel ve işitsel anlamda maruz kalmalarını sağlayacak ortamları düzenlemesi beklenmekte ve öğretmenin sadece gerek duyduğu durumlarda Türkçe kullanması önerilmektedir ki, bu durum da öğretmenin uygulamada daha çok esnekliğe sahip olması ile açıklanabilir. Buna rağmen, 2014 ve 2016 programlarında sınıf ortamında her zaman İngilizce kullanılarak öğrencilere model olunması gerektiği ve öğrencilerin de sınıfta her zaman İngilizce dilinde iletişime geçmelerinin hedeflendiği belirtilmiştir. Programda bunun belirtilmesi esneklik açısından olumsuz bir açıklama olarak görülse de, programın savunduğu iletişimsel yaklaşımın başarıya ulaşmasında önemli bir öneri olabilir.

2014 ve 2016 programlarının öğrencilere ve öğretmenlere yüklediği sorumluluklar açısından kullanışlı ve esnek olduğu söylenebilir. Örneğin bu programlarda öğretmenlerin, öğrencilerin ilgi, ihtiyaç ve yeteneklerini göz önünde bulundurarak sınıf ortamındaki etkinlikleri düzenlemesi beklenmektedir ve öğrencilerin kendi kendine öğrenen bireyler olarak ele alınması sonucu çok yönlü öğrenme ortamları desteklenmektedir. Programların esnek olduğunu gösteren diğer bir kanıt ise haftalık ders saatinin her sınıf seviyesi için belirtilmesine rağmen gerekli durumlarda öğretmenlerin bunu düzenleyebilecekleridir (MEB, 2016, s. 9). Ancak 2002 programında öğrenci merkezli yaklaşım benimsenmesine karşın bazı 
bilinmeyen kelimelerin açıklanmasının öğrenciler değil de öğretmen tarafından yapılması gibi öneriler, iletişimsel öğretim anlayışıyla bağdaşmamaktadır (s. 110). Öğrenmede bireysel farklılıklar açısından incelendiğinde, tüm programlarda öğrencilerin görsel ve işitsel alanları başta olmak üzere diğer zekâ alanlarını da temel alan materyaller ve etkinlikler yer almıştır.

2002 programında esnekliğin göstergelerinden biri olan kültürel çeşitliliğin yansıtılması ile ilgili “Türkler için özel bir günle ilgili konuşma hazırlama”, “Türkiye Cumhuriyeti ve Atatürk'ün Türk toplumuna etkisi ile ilgili kısa bilgi vermesi” gibi bazı örnekler bulunmaktadır (s. 58, 60). Benzer şekilde, diğer yıllara ait programlarda bazı temalarda öğrencilerin kendi kültürlerine uyarlayabilecekleri "milli bir festival anlatma”, “Anadolu'da eski bir uygarlık hakkında konuşma yapma” (MEB, 2016); “öğrencilerin Türkiye'de gezilecek yerleri öneren bir mektup yazması" (MEB, 2014); “İngilizce konuşulan ülkelerin kültür değerleri hakkında konuşma" (MEB, 2011) gibi hedeflerin seçilmesi programların farklı bireylere hitap etmesi ve kültürel çeşitliliği yansıtması yönleriyle esnekliğine olumlu katkıda bulunmuştur. Hatta 2014 ve 2016 programlarında kültürel farkındalık diye ayrı bir bölüm hazırlanarak hangi temalarda nasıl etkinlikler yapılarak diğer kültürler hakkında bilgi sahibi olunabileceği açıklanmıştır. Örneğin; cinsiyet eşitliği, özel ihtiyaçları olan bireylerin hakları, dünyada değişik yeme alışkanlıklarl, değişik ülkelerdeki ergenlerin favori TV programları gibi konuşma konularının önerilmesi programın esnekliğine verilebilecek örneklerdir (MEB, 2016, s. 20, 21). Tüm programlarda özel eğitime ihtiyacı olan bireylerle ilgili bir açıklama ya da yönergenin olmadığı görülmektedir. Ancak 2016 programında engelli olimpiyatları (s. 83) gibi temaların seçilmesi bir farkındalık uyandırmak amacıyla hazırlanmış olabilir.

2002 ve 2011 programlarında her sınıf seviyesi için ayrıntılı örnek bir ders planı hazırlanmasına rağmen, bu planların kaç kişilik bir sınıf için uygun olduğu belirtilmediğinden, hedeflere ulaşılması için düzenlenen etkinliklerin beklenenden daha uzun zaman alması ihtimali vardır ve bu durum programın kullanışlılığını olumsuz etkilemektedir. Bununla birlikte, 2011 programında dil yeterlilik seviyelerini belirlemek amacıyla dönem başında bir sınavın uygulanması önerilmiştir; ancak ülke genelinde fiziki yapının ve öğretmen durumunun uygun olmaması nedeniyle her okulda öğrencilerin dil yeterliliklerine göre sınıflandırılması pek mümkün görünmemektedir. 2014 ve 2016 programlarında ise örnek ders planları sunulmadığı için programın kaç kişilik öğrenci grupları için uygun olabileceği konusunda net bir bilgi yoktur. 
2002, 2014 ve 2016 programlarında genel olarak yazım ve dilbilgisi kurallarına uygun ifadeler bulunmaktadır. Ancak 2011 programında çok sayıda yazım hatası göze çarpmaktadır ve bu durum programın okunmasını güçleştirmekte, ilgiyi dağıtmaktadır. Örneğin, 160. sayfada defalarca dinlemek becerisi yerine dinlenmek sözcügü kullanılmış, 163. sayfada numaralandırılan hedeflerin bazıları büyük harfle başlarken bazıları küçük harfle başlamıştır. Bu hatalar daha birçok sayfada tekrarlanmış ve "basit kurgulu”, "öğrencinin kendi ilgi alanına giren konularda" gibi yarım kalan ifadeler ise programın ciddiyetine zarar vererek hedeflerin taslak benzeri bir çalışma olarak kaldığı izlenimini yaratmıştır (s. 119). Yine bazı bölümlerde hedefler numaralandırılmasına rağmen sırayla verilmemiştir; bu da metnin anlaşılmasını güçleştirmektedir (s. 149).

2002 programında öğretmenlerin programla ilgili görüş ve önerilerini belirtebilecekleri herhangi bir bağlantı, e-posta adresi, telefon vb. iletişim bilgisine yer verilmemiştir. Aynı şekilde 2011, 2014, 2016 programlarında da böyle bir bilgi mevcut değildir, ancak bu yıllarda kaynakçanın belirtilmesi ve program boyunca kullanılan terimlerin açıklanması programların hazırlanırken kullanışlılık ilkesinin göz önünde bulundurulduğunu göstermektedir. 2011 yılında Türkçe yayımlanan Ortaöğretim İngilizce Dersi Öğretim Programı 561 sayfadan oluşmaktadır ve 2002 programında hakkında bilgi verilmeyen yazar bilgileri, 2011 programında liste halinde sunulmuştur (s. 3). Bu bilginin sunulması kullanışlılık açısından önemli olsa da sayfa sayısının çokluğu, öğretmenlerin bu program metnini okumasını ve anlamasını güçleştirmiş olabilir. Bununla birlikte, 2014 ve 2016 programlarında tüm sınıf ve dil yeterlik düzeylerinde olması gereken teknolojik donanıma kaç okulun, öğretmenin ve öğrencinin sahip olduğu, eğer bu donanım yoksa önerilen teknoloji odaklı değerlendirme ürünlerinin nasıl hazırlanılacağı belirtilmemiştir. $\mathrm{Bu}$ duruma öneri olarak materyal hazırlayanların öğretmenlere kılavuz hazırlaması gerektiği belirtilmiş ve İngilizce öğretmenlerinin çevrimiçi topluluklarda fikir alışverişinde bulunmaları halinde hazırlanan programın daha etkili olacağı belirtilmiştir (MEB, 2014, s. iii; MEB, 2016, s. 9).

\section{Tartışma, Sonuç ve Öneriler}

Araştırmada elde edilen bulgular 1şı̆̆ında, İngilizce öğretimi alanında ortaya çıkan bilimsel gelişmelerin son 15 yıl içinde hazırlanan programlara yansıdığı görülmektedir. Programlarda tüm Avrupa Birliği ülkelerinde yabancı dil eğitim programlarının şekillenmesini sağlayan ortak ölçütlere "Diller İçin Avrupa Ortak Başvuru Metni” (Council of Europe, 2001) AB üyesi olmak ve çağın gerisinde kalmamak amacıyla uyum sağlandığı görülmektedir. 
İlköğretim 2006 ve 2013 yılları İngilizce Dersi Öğretim Programlarında iletişimsel dil becerilerini geliştirmeye dönük, öğrenci merkezli bir öğretim yaklaşımının benimsendiği söylenebilir. Yapılan incelemelere göre her iki programın da genel olarak kapsam, aşamalılık, süreklilik ve denge ilkelerine uygun olarak tasarlandığı ancak öngörülen sürelerin yetersiz olduğu anlaşılmaktadır. Programların başlangıç düzeyi kullanıcıları tanımlarına göre ve öğrencilerin gelişim özelliklerini dikkate alarak tasarlanmış olmaları, denge ilkesine uygun davranıldığını göstermektedir. Bu bulguyla ilgili olarak, öğretmen görüşlerine göre her iki programın da öğrencilere uygun olduğunu gösteren araştırmalar bulunmaktadır (Topkaya ve Küçük, 2010; Yıldıran ve Tanrıseven, 2015). Programlarda öğrencilerin iletişimsel dil becerilerini geliştirmeleri amacıyla derse etkin katılımlarını sağlayacak yöntem ve tekniklere yer verildiği, önerilen materyal türlerinin de buna uygun olduğu ve içeriğgin aşamalılık ilkesine göre düzenlendiği görülmüştür. Benzer bulgulara Dönmez (2010) ve Yüceer, Esen ve Yağc1 (2016) tarafından yapılan araştırmalarda rastlansa da, programlara yönelik eleştirilere bakıldığında tasarlanan program ile uygulanan program arasındaki fark açık bir şekilde ortaya çıkmaktadır. 2013 programının uygulanmasında öğretmenlerin kullandığı yöntemlerin öğrenci merkezli anlayıştan uzak olması, öğrenci etkileşimini engelleyen fiziki ortamda iletişimsel yaklaşımın göz ardı edilerek dilbilgisi kurallarının aktarılması ve ayrıca tasarıda uygulama düzeyine çıkan hedefler bulunmasına rağmen öğretmenlere göre hedeflerin bilgi ve kavrama düzeyinde kalması (Kozikoğlu, 2014); tasarlanan programın uygulanan programdan farklı olduğunu göstermektedir. Bunun nedeni öğretmenlerin motivasyonlarının düşük ve mesleki anlamda yetersiz olmalarından (Çelik ve Kasapoğlu, 2014) veya programın öğretmenlere yeterince tanıtılmamış olmasından (Alkan ve Arslan, 2014; Demirtaş ve Erdem, 2015; Küçüktepe, Küçüktepe ve Baygın, 2014; Seçkin, 2011; Topkaya ve Küçük, 2010) kaynaklanabilir.

İlköğretim programları incelendiğinde, gerek kullanılan dil gerekse yapı olarak kullanışlılık özelliğine sahip oldukları düşünülmektedir. Ancak ilgili araştırmalarda (Demirtaş ve Erdem, 2015; Yıldıran ve Tanrıseven, 2015) öğretmenlerin programla ilgili yeterince bilgilendirilmediklerini belirtmeleri, bu programları okumadıkları veya okumuş olsalar da anlayamadıkları anlamına gelebilir. Tasarlanan programla uygulanan program arasındaki farklılığın başka bir nedeni de haftalık ders saatlerinin yetersiz olmasıdır. İlgili araştırmalarda öğretmenlerin programları uygulamak için ayrılan süreyi yetersiz buldukları ve bunun yanında kalabalık sınıf mevcutlarından şikâyet ettikleri görülmektedir (Çelik ve Kasapoğlu, 2014; Dönmez, 2010; Seçkin, 2011; Yüceer ve diğ., 2016). Programlara yöneltilen 
eleştirilerden ders kitaplarının sıkıcı ve içeriğin yüklü olması durumu (Demirtaş ve Erdem, 2015; Dönmez, 2010; Yıldıran ve Tanrıseven, 2015), programın uygulanmasında en temel araç olan ders kitabının program tasarımına uygun olmadığını düşündürmektedir. Tasarlanan programların uygulamada farklılaştığına işaret eden bir başka bulgu ise görsel ve işitsel materyallerin bolca kullanılmasını gerektiren dil öğrenme ortamlarında öğretmenlerin ders araç gereçlerinin temininde yaşadıkları zorluklardır (Küçüktepe ve diğ., 2014; Seçkin, 2011; Topkaya ve Küçük, 2010; Yüceer ve diğ., 2016). Öte yandan 2013 ilköğretim programının tasarlanma sürecinin analiz edildiği bir çalışmada (Kırkgöz, Çelik ve Arıkan, 2016), bu araştırmanın bulgularını destekleyecek şekilde; programın $\mathrm{AB}$ dil öğretme standartlarına uygun şekilde tasarlandığı, sarmal program yaklaşımının benimsendiği, öğrencilerin aktif olacağı etkinlik türlerinin seçildiği belirtilse de, bu araştırmanın ve ilgili araştırmaların sonuçlarının aksine; sınıf mevcutlarının ve teknoloji kullanımının dikkate alındığı ifade edilmektedir. Bu durumda yeni program tasarılarında görgül araştırma bulgularının daha çok dikkate alınması gerektiği düşünülmektedir.

İlköğretim İngilizce Dersi Öğretim Programlarının incelenmesi sonucu ortaya çıkan bu tablo, öğretim programlarının tasarlandığı gibi uygulanamadığını gösteren çalışmaları doğrulamaktadır (Bümen, Çakar ve Yıldız, 2014; Çelik, 2012). Bu bağlamda, öncellikle öğretmenlerin programları etkili bir şekilde uygulayabilmeleri için uygulamalı mesleki gelişim programları yürütülmelidir. $\mathrm{Bu}$ eğitimlerde programları bir doküman olarak nasıl kullanmaları gerektiğine dair uygulamalı çalışmalar yürütülmelidir. Ders kitaplarının seçimi, bu programları daha önce uygulamış olan öğretmenlerden oluşan komisyonlar tarafından yapılmalıdır. Ayrıca program hazırlık çalışmalarında öğretmen görüşleri önemsenmelidir. İngilizce derslerinde kalabalık sınıf mevcutları azaltılmalıdır. Haftalık İngilizce ders saatleri, öğrencilerin hedeflenen dil yeterliklerine ulaşabilmeleri için arttırılmalıdır. Zengin materyal çeşitliliği ile desteklenen İngilizce öğrenme ortamlarının oluşturulması için okulların donanımı ve teknolojik alt yapısı sağlanmalıdır. Aksi takdirde, program çalışmalarına harcanan onca zaman ve emek boşa gidecek ve programlar hayata geçirilememiş birer evrak olarak kalacaktır.

Araştırmanın ortaöğretim programları ile ilgili bulguları genel olarak incelendiğinde, tasarım ilkelerinden özellikle aşamalılık ve sürekliliğe özen gösterildiği söylenebilir. Ortaöğretim programlarının tümünde dilin bütüncül bir şekilde sunulduğu ve gerçek yaşamla ilişki kurulduğu için kaynaşıklık ilkesinin göz önünde bulundurulduğu da görülmüştür. İçerik açısından oldukça yoğun olan bu programlarda süre ve esneklik ilkesi açısından da problemler 
olacağı düşünülmektedir. Bununla birlikte, 2002, 2014 ve 2016 programlarının gerek kullanılan dil gerekse yapı olarak kullanışlılık ilkesini dikkate aldığı, ancak 2011 programının çok uzun ve karmaşık olduğu görülmüştür.

2002 yılı ortaöğretim programındaki hedeflerin bazı eksikliklerinin olduğu, 2011 yılında ise hedeflerin hiç anlaşılır olmadığı ve programın diğer öğeleriyle uyumsuz olduğu görülmektedir. Ancak 2014 ve 2016 yıllarına ait programlarda hedeflerin ilgili dil işlevleri ve temalarla ilişkilendirilerek hazırlandığı için anlaşılmasının daha kolay olduğu söylenebilir. İlgili alanyazında da 2011 ortaöğretim programı hedeflerinin programın diğer öğeleriyle tutarsızlığı dile getirilmiştir (Merter ve diğ, 2012). Aynı şekilde 2011 yılı ortaöğretim programının önerdiği etkinlikler ve örnek ders planları incelendiğinde, öngörülen sürenin yetersiz olacağı ve bir ders saati için beklenen hedeflerin çok fazla olduğu diğer araştırmalarda da dile getirilmektedir (Karc1, 2012; Merter ve diğ., 2012).

2011 ortaöğretim İngilizce dersi programının içeriğinin, ilgili konu ve dil işlevleri açısından değil de hedefler açısından hazırlanması sonucunda denge ilkesinin göz önüne alınmadığı düşünülmektedir. Hâlbuki Swan'ın (2012) da bahsettiği gibi, öğrencilerin ilgi ve ihtiyaçlarının programın temelinde olması gerekmektedir; aksi halde diğer çalışmalarda da karşımıza çıkan konuların ve etkinliklerin öğrencilerin ilgisini çekmemesi sebebiyle uygulamada problemler yaşanması olasıdır (Karcı, 2012).

2002, 2011, 2014 ve 2016 ortaöğretim programlarının vizyonunun açıklandığı bölümde, öğrencileri dinleyen, konuşan, okuyan ve yazan bireyler olarak yetiştirmenin amaçlandığ görülmektedir. Canale ve Swain (1980), öğrenci gereksinimlerinin iletişimsel yeterlik alanları dikkate alınarak belirlenmesi gerektiğini vurgulamıştır. Bu kapsamda, dört temel becerinin bütünleşik olarak öğrencilere sunulması; böylece anlam odaklı bir öğrenme ortamı yaratılması hedeflenmiştir. Ancak sınıf içi uygulamalarda iletişimsel yaklaşımın uygulanamadığı ve dört becerinin öğretim ve değerlendirme süreçlerinde istenildiği gibi kazandırılamadığ1 öğretmenler tarafından sıkça ifade edilmiştir. Bu bağlamda alanyazında değerlendirmenin becerilere yönelik değil; dilbilgisine yönelik yapıldığı yönünde bulgulara rastlanmış (Karcı, 2012; Soğuksu, 2013; Topkaya ve Küçük, 2010), öğrencilerin özellikle konuşma ve yazma gibi becerilerinin değerlendirilmesi göz ardı edilmiştir.

İletişimsel yaklaşımın benimsendiği ortaöğretim programlarında öğretmenin rolü, iletişimsel bir sınıf ortamı sağlamak, öğrencilere kılavuzluk etmek ve öğrenme sürecini kolaylaştırmaktır (Breen ve Candlin, 1980). Hazırlanan programlarda bu rolün öğretmenlere 
yüklendiği görülmektedir. Ancak öğretmenlerin bu konuda bilgilendirilmemesi (Seçkin, 2011) ve motive edilmemesi (Kızıldağ, 2009) uygulamada etkileşimin öğretmen merkezli (Dönmez, 2010; Soğuksu, 2013) olduğunu göstermektedir.

Öğrencilerin, hedef dili iletişimsel gereksinimlerini karşılamak amaciyla kullanabilmesi için, iletişimsel yeterliğin tüm alanlarında gelişim sağlamaları gerekmektedir (Breen ve Candlin, 1980; Canale ve Swain, 1980). Bu bağlamda programlarda, dil yapısına odaklanılması yerine anlama odaklanılması, daha işlevsel bir öğrenme ortamı sağlayabilir. Dilbilgisi kurallarının öğrencilere sezdirilerek verilmesi gerektiğini belirten 2011 ortaöğretim programının bu yönü alanyazında da olumlu bir görüş olarak desteklenmiştir (Merter ve diğ., 2012). Ancak önerilen etkinlik türleri incelendiğinde boşluk doldurma, yüksek sesle okuma, dinlenen ya da okunan bir metinle ilgili soruları yanıtlama gibi etkinliklerin programda sıklıkla yer aldığı görülmüş̧ür. Bu tür etkinlikler, anlamdan çok dilin yapısına odakladığından anlamlı ve işlevsel bir sınıf ortamı oluşturulamamakta ve bu durum bazı araştırma bulgularıyla da örtüşmektedir (Kızıldağ, 2009; Kozikoğlu, 2014; Seçkin, 2011).

Sonuç olarak, MEB tarafından hazırlanan ilköğretim ve ortaöğretim İngilizce dersi öğretim programlarının, program tasarım ilkeleri açısından yıllar içinde bir gelişim gösterdiği söylenebilir. Dil eğitimi alanında dünyadaki gelişmelerin takip edildiği ve yeniliklerin programlara dâhil edilmeye çalışıldığı görülmüştür. İlköğretim programlarının, esneklik ilkesi dışında genel olarak tasarım ilkelerine uygun olduğu ancak önerilen sürelerin yetersiz kaldığı sonucuna varılmıştır. Elde edilen bulgular ve ilgili araştırmalar ışı̆̆ında, okul merkezli ve uygulamalı mesleki gelişim programlarının yürütülmesi, program geliştirme çalışmalarında ve ders kitaplarının seçiminde öğretmen görüşlerinin dikkate alınması, haftalık ders saatlerinin arttırılması, sınıf mevcutlarının azaltılması, okullarda gerekli donanımın sağlanması ve öğretmenlere somut uyarlama seçenekleri sunulması önerilebilir.

Ortaöğretim İngilizce dersi öğretim programları açısından ise, iletişimsel yaklaşıma geçiş sürecinde bazı sıkıntılar olduğu fakat 2016 yılında yayımlanan öğretim programında bunun büyük ölçüde düzeltilerek, programın kendi içinde bir bütünlük ve uyum sağladığ1 görülmüştür. 2011 programının kapsam ve kullanışlılık ilkesi açısından yarattığı sorunlar, 2014 ve 2016 programlarında büyük ölçüde giderilmiştir. Programların aşamalılık, süreklilik ve kaynaşıklık ilkeleri açısından uygun olduğu ancak kapsam, denge, kullanışlılık ve esneklik ilkeleri açısından sıkıntıları olduğu düşünülmektedir. Programların bu ilkeler açısından gözden geçirilmesi, pilot çalışmalar hakkında bilgi verilmesi, yerel bağlam düşünülerek 
Ege Eğitim Dergisi 2017 (18) 2: $702-737$

Son 15 Yılda Yayımlanan İlk ve Ortaöğretim İngilizce Dersi Öğretim Programları Üzerine Bir Analiz

uyarlama seçenekleri sunulması, okul temelli ve uygulamalı mesleki gelişim programlarının uygulanması önerilebilir. Alanyazında ortaöğretim İngilizce dersi öğretim programlarıyla ilgili çok sınırlı araştırma bulunduğundan, özellikle uygulamada karşılaşılan sorunlar hakkında ve program değerlendirmeye yönelik çalışmalar yapılmalıdır. 


\section{Kaynakça}

Alkan, M. F. ve Arslan, M. (2014). İkinci sınıf İngilizce öğretim programının değerlendirilmesi. International Journal of Curriculum and Instructional Studies, 4(7), $87-98$.

Breen, M. P. ve Candlin, C. N. (1980). The essentials of a communicative curriculum in language teaching. Applied Linguistics 1(2), 89-111.

Bümen, N. T., Çakar, E. ve Yıldız, D. G. (2014). Türkiye'de öğretim programına bağlılık ve bağlılı̆̆1 etkileyen etkenler. Kuram ve Uygulamada Ĕ̈itim Bilimleri, 14(1), 203-228.

Canale, M. ve Swain, M. (1980). Theoretical bases of communicative approaches to second language teaching and testing. Applied Linguistics, 1(1), 1-47.

Council of Europe (2001). Common European framework of reference for languages:

Learning,aching, assessment. Cambridge: Cambridge University Press.

Çelik, Z. (2012). Politika ve uygulama bağlamında Türk ĕgitim sisteminde yaşanan dönüşümler: 2004 ilköğretim müfredat reformu örneği. (Yayımlanmamış doktora tezi). Hacettepe Üniversitesi, Ankara. YÖK Ulusal Tez Merkezi veri tabanından elde edildi. (Tez no: 308505).

Çelik, S. ve Kasapoğlu, H. (2014). Implementing the recent curricular changes to English Language instruction in Turkey: Opinions and concerns of elementary school administrators. South African Journal of Education, 34(2), 1-14.

Demirtaş, Z. ve Erdem, S. (2015). Beşinci sınıf İngilizce dersi öğretim programı: Güncellenen programın bir önceki programla karşılaştırılması ve programa ilişkin öğretmen görüşleri. Sakarya University Journal of Education, 5(2), 55-80.

Demirel, Ö. (2006). Kuramdan uygulamaya eğitimde program geliştirme. Ankara: PegemA Yayınc1lı.

Dikbayır, A. (2016). Öğretim programı uyum ölçeği. İkili görüşme, 12 Aralık 2016, İzmir.

Doğan, H. (1982). Analiz ve program hazırlama. Ankara Üniversitesi Eğitim Bilimleri Fakültesi Yayınları No:120.

Doğanay, A. (2008). Öğretim ilke ve yöntemleri. Ankara: PegemA Yayıncılık.

Dönmez, Ö. (2010). Implementation of the new eighth grade english language curriculum from the perspectives of teachers and students. (Yayımlanmamış yüksek lisans tezi). Orta Doğu Teknik Üniversitesi, Ankara. YÖK Ulusal Tez Merkezi veri tabanından elde edildi. (Tez no: 277958).

ERG (2005). Yeni Öğretim Programlarını İnceleme ve Değerlendirme Raporu. Sabancı 
Üniversitesi, Eğitim Reformu Girişimi. [Online]: http://www.erg.sabanciuniv.edu/ adresinden elde edildi.

Gözütok, D., Bıkmaz, F., Mızıkacı, F., Şahin, S., Ulubey, Ö., Koçer, E., Türe, E. ve Akçatepe, A. (2013). Cumhuriyet'in ilanindan 2013'e ögretim programlarmin analizi: Hayat bilgisi örneği. Ankara: Yargı Yayınevi.

Hewitt, T. (2006). Understanding and shaping curriculum: What we teach and why. California: Sage Publications Inc.

Hismanoglu, M. (2013). Does english language teacher education curriculum promote CEFR awareness of prospective EFL teachers? Procedia-Social and Behavioral Sciences, 93, 938-945.

İnceçay, G. (2012). Turkey's foreign language policy at primary level: Challenges in practice. ELT Research Journal, 1, 53-62.

Karc1, C. (2012). Ortaöğretim dokuzuncu sinıf İngilizce dersi öğretim programina ilişkin ögretmen görüşlerinin değerlendirilmesi. (Yayımlanmamış yüksek lisans tezi). Adnan Menderes Üniversitesi, Aydın. YÖK Ulusal Tez Merkezi veri tabanından elde edildi. (Tez no: 312386).

Kurkgöz, Y. (2007). English language teaching in Turkey: Policy changes and their implementations. Regional Language Center Journal, 38, 216-228.

Kurkgöz, Y. (2008). A case study of teachers' implementation of curriculum innovation in English language teaching in Turkish primary education. Teaching and Teacher Education, 24(7), 1859-1875.

Kırkgöz, Y., Çelik, S. ve Arıkan, A. (2016). Türkiye'deki yeni ilköğretim ingilizce programın teorik ve pratik temellerinin incelenmesi: Bir süreç analizi. Kastamonu Eğitim Dergisi, 24 (3) 1199-1212.

Kızıldağ, A. (2009). Teaching english in Turkey: Dialogues with teachers about the challenges in public primary schools. International Electronic Journal of ElementaryEducation, 1(3), 188-201.

Kozikoğlu, İ. (2014). Ortaokul 7. Sınıf İngilizce öğretim programının değerlendirilmesi.

Abant İzzet Baysal Üniversitesi Eğitim Fakültesi Dergisi, 14(1), 361-375. Doi: http://dx.doi.org/10.17240/aibuefd.2014.14.1-5000091517.

Küçüktepe, C., Küçüktepe,S. ve Baykın, Y. (2014). İkinci sınıf İngilizce dersi ve programına ilişskin öğretmen görüşlerinin incelenmesi. Hasan Ali Yücel Eğitim Fakültesi Dergisi. $11(22), 55-78$. 
MEB (2002). Anadolu lisesi (Hazırlı sınıfı ve 9,10,11 sinıflar) Ingilizce dersi öğretim programı. Ankara: Milli Eğitim Basımevi.

MEB (2006). İlkögrretim İngilizce dersi (4, 5, 6, 7 ve 8. sinıflar) ögretim programı. Ankara: Milli Eğitim Basımevi.

MEB (2011). Ortaöğretim kurumları İngilizce dersi ögretim programı. Ankara: Milli Eğitim Basımevi.

MEB 2013). İlköğretim kurumları (ilkokullar ve ortaokullar) İngilizce dersi (2, 3, 4, 5, 6, 7 ve 8. sınıflar) öğretim programı. Ankara: Milli Eğitim Basımevi.

MEB (2014). Ortaöğretim İngilizce dersi (9, 10, 11 ve 12. sinıflar) öğretim programı. Ankara: Milli Eğitim Basımevi.

MEB (2016). Hazırlık sınıfı bulunan ortaöğretim kurumları İngilizce dersi (Hazırlık, 9, 10, 11 ve 12. sınıflar) öğretim programı. Ankara: Milli Eğitim Basımevi.

Merter, F., Kartal, Ş. ve Çağlar, İ. (2012). Ortaöğretim İngilizce dersi yeni öğretim programının öğretmen görüşlerine göre değerlendirilmesi. Mehmet Akif Ersoy Üniversitesi Eğitim Fakültesi Dergisi, 1(23), 43-58.

Ornstein, A.C. ve Hunkins, F. P. (2009). Curriculum: Foundations, principles and issues. US: Pearson.

Özçelik, D. A. (2014). Eğitim programları ve öğretim. Ankara: Pegem Akademi.

Posner, G. (1995). Analysing the curriculum. US: McGraw-Hill, Inc.

Resmi Gazete. (2012, Nisan 11). İlköğretim ve ĕgitim kanunu ile bazı kanunlarda değişiklik yapılmasina dair kanun. [Online]: http://www.resmigazete.gov.tr/eskiler/2012/04/20120411-8.htm adresinden elde edildi.

Seçkin, H. (2011). İlköğretim 4. sınıf İngilizce dersi öğretim programına ilişkin öğretmen görüşleri. Uluslararası Insan Bilimleri Dergisi, 8(2), 550-577. [Online]: https://www.jhumansciences.com/ojs/index.php/IJHS/article/download/1721/805 adresinden elde edildi.

Soğuksu, A. F. (2013).Ortaöğretim İngilizce dersi öğretim programındaki iletişimsel yaklaşımın sınıf içi uygulamalara yansıması (Yayımlanmamış yüksek lisans tezi). Ankara Üniversitesi, Ankara. YÖK Ulusal Tez Merkezi veri tabanından elde edildi. (Tez no: 342478).

Sönmez, V. (2007). Program geliştirmede ögretmen elkitabı. Ankara: Anı Yayıncılık. Swan, M. (2012). Thinking about language teaching. Oxford: Oxford University Press. Tan, Ş. (2011). Öğretim ilke ve yöntemleri. Yedinci Baskı, Ankara: PegemA Yayıncılık. Tan, Ş. ve Erdoğan, A. (2004). Öğretimi planlama ve değerlendirme. Ankara: PegemA 
Yayınc1lı.

TEPAV (2014). Türkiye'deki devlet okullarında İngilizce dilinin öğretimine ilişkin ulusal ihtiyaç analizi. [Online]: http://www.tepav.org.tr/upload/files/13993885191.Turkiyedeki_Devlet_Okullarinda_Ingilizce_Dilinin_Ogrenimine_Iliskin_Ulusal_Ihtiy ac_Analizi.pdf adresinden elde edildi.

Topkaya, E. Z. ve Küçük, Ö. (2010). An evaluation of the $4^{\text {th }}$ and $5^{\text {th }}$ grade English language teaching program. Ilkögretim Online, 9, 52-65.

TTKB, (2013) . Öğretim programlart. [Online]:

http://ttkb.meb.gov.tr/program2.aspx ?islem=1\&kno=214 adresinden elde edildi.

Varış, F. (1989). Eğitimde program geliştirmeye sistematik yaklaşım. Ankara Üniversitesi Ĕ̌itim Bilimleri Dergisi, 22(1), 7-12. Doi: 10.1501/Egifak 0000000866.

Yıldıran, C. ve Tanrıseven, I. (2015). İngilizce öğretmenlerinin ilkokul 2. sınıf İngilizce dersi öğretim programı hakkındaki görüşleri. International Journal of Language Academy, $3(1), 210-223$.

Yıldırım, A. ve Şimşek, H. (2013). Sosyal bilimlerde nitel araştırma yöntemleri. Ankara: Seçkin Yayıncılık.

Yüceer, Y., Esen, E. ve Yağcı, E. (2016). Yabancı dil öğretimi ve ilkokul 2. sınıf İngilizce öğretim programına ilişkin öğretmen görüşleri. 4. Uluslararası Eğitim Programları ve Öğretim Kongresi Tam Metin Kitabı.[Online]: http://www.icci-epok.org/ICCIEPOK_Tam_Metin_son.pdf adresinden elde edildi. 


\section{Extended Summary}

Although students receive English language education for 12 years, they cannot reach the expected language level and this shows there are problems with the language education and language curricula in Turkey. Despite the existence of studies which examine the implementation of English language curricula published by the Ministry of National Education (MoNE) for different grades depending on the teachers' views, no research examining the primary and secondary education curricula across different years has been found. Aiming to fill this gap, in this study the primary and secondary education English language curricula published over the last 15 years were analyzed according to the indicators based upon the principles of curriculum design. It is considered that the study will contribute to the field as it can provide a resource to follow the progress in the English language curricula in Turkey and by proposing solutions for the parts which need improvement, it has the potential to enlighten future curriculum studies.

For the research method, document analysis as a qualitative research method was used to examine 2006, 2013 primary education and 2002, 2011, 2014, 2016 secondary education English language curricula. The principles of curriculum design (scope, sequence, articulation, continuity, balance, user-friendliness and flexibility) were determined according to the literature and were chosen as the themes used in descriptive analysis. For each theme, indicators were described and the curricula were analyzed. Then the studies related to the curricula in question were categorized and associated to the findings obtained from the themes.

According to the findings, the communicative approach was adopted both in primary and secondary school English language curricula. Analyzed in terms of scope, objectives were seen to be chosen mostly from the cognitive domain and remained at the level of application; however, in 2013 the curriculum objectives from the affective domain were more easily noticed. Moreover, listening and speaking skills, ignored in the assessment part in the 2006 curriculum, were integrated in the 2013 curriculum. Nevertheless, allocated time was considered to be not enough in terms of objectives and content. It also seemed that the balance principle was taken into consideration as the content was designed according to the learners' developmental levels. The spiral design of both curricula indicated that the continuity principle was the basis. The relationship among the components of the curricula as well as the compliance of the language with the daily one indicated the presence of the articulation 
principle. It could also be stated that the curricula were applicable regarding the language used and the formal structure. Nonetheless, not providing opportunities for learner differences, not including any information about the required physical conditions, class size or sources that teachers could use, all showed the lack of the flexibility principle in the curricula.

Alternately, in the secondary school curricula it was noticeable that especially the sequence and continuity principles were considered. However, the allocated time was not enough to achieve the objectives. In the 2011 curriculum, the incompliance among the components and the absence of the balance principle were each noticeable in this study and in the literature. Besides, in the 2002, 2014 and 2016 curricula, the user-friendliness principle was clearly noticed with regard to the language used and the formal structure, despite the long and complicated 2011 curriculum. It could be stated that the articulation principle was considered in all secondary school curricula as the language was presented in an integrated approach and related to real life. The suggested time for the heavily-loaded content in these curricula indicated the absence of the flexibility principle.

In conclusion, primary and secondary school education English lesson curricula prepared by the MoNE (Ministry of National Education) could be said to have shown an improvement over the years in terms of the principles of curriculum design. It was seen that global trends in the field of language education were followed and innovations were included in the curricula. It was concluded that primary education curricula were mostly in conformity with the principles of curriculum design except for flexibility but they failed to satisfy the time proposed. In the light of the findings and related studies, it could be recommended to implement school based professional development programs, pay attention to teacher views for the selection of course books and curriculum design process, increase weekly course hours, decrease classroom size, provide necessary equipment at schools and offer teachers alternatives for concrete adaptations.

With regard to secondary education English lesson curricula, it was observed that there had been some problems in the transition process to communicative approach but the curriculum published in 2016 showed integrity and compatibility in itself through solving the problems mostly. It was thought that secondary education curricula were appropriate in terms of the principles of sequence, continuity and articulation whereas they had some problems in terms of the principles of scope, balance, applicability and flexibility. It could be suggested to revise the curricula regarding these principles, giving information about pilot studies, offering 
Ege Eğitim Dergisi 2017 (18) 2: $702-737$

Son 15 Yılda Yayımlanan İlk ve Ortaöğretim İngilizce Dersi Öğretim Programları Üzerine Bir Analiz

options of adaptation considering local context and implement school-based and professional development programs. Since there is very limited research on secondary education English lesson curricula in the literature, there need to be studies about the problems experienced in the implementation of the curricula and curriculum evaluation. 